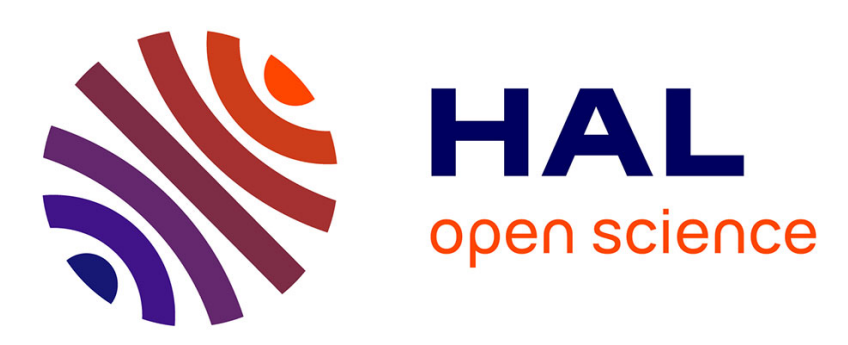

\title{
Modeling evidences for global warming, Arctic seawater freshening, and sluggish oceanic circulation during the Early Toarcian anoxic event
}

Guillaume Dera, Yannick Donnadieu

\section{- To cite this version: \\ Guillaume Dera, Yannick Donnadieu. Modeling evidences for global warming, Arctic seawater fresh- ening, and sluggish oceanic circulation during the Early Toarcian anoxic event. Paleoceanography, 2012, 27 (2), pp.PA2211. 10.1029/2012PA002283 . hal-02902772}

HAL Id: hal-02902772

https://hal.science/hal-02902772

Submitted on 14 Jun 2021

HAL is a multi-disciplinary open access archive for the deposit and dissemination of scientific research documents, whether they are published or not. The documents may come from teaching and research institutions in France or abroad, or from public or private research centers.
L'archive ouverte pluridisciplinaire HAL, est destinée au dépôt et à la diffusion de documents scientifiques de niveau recherche, publiés ou non, émanant des établissements d'enseignement et de recherche français ou étrangers, des laboratoires publics ou privés. 


\title{
Modeling evidences for global warming, Arctic seawater freshening, and sluggish oceanic circulation during the Early Toarcian anoxic event
}

\author{
Guillaume Dera ${ }^{1}$ and Yannick Donnadieu ${ }^{2}$ \\ Received 12 January 2012; revised 18 April 2012; accepted 24 April 2012; published 13 June 2012.
}

[1] The paleoecological disturbances recorded during the Early Toarcian warming event (183 Myr ago), including marine anoxia, sea level rise, seawater acidification, carbonate production crisis, and species extinctions, are often regarded as past examples of Earth's possible responses to the rapid emergence of super greenhouse conditions.

However, physical mechanisms explaining both the global and local expressions of paleoenvironmental events are still highly debated. Here we analyze the paleoclimatic and paleoceanographic consequences of increases in atmospheric $p \mathrm{CO}_{2}$ levels at a multiscale resolution using a fully coupled ocean-atmosphere model (FOAM). We show that, in association with stronger high-latitude precipitation rates and enhanced continental runoff, the demise of polar sea ice due to the global warming event involved a regional freshening of Arctic surface seawaters. These disturbances lead to progressive slowdowns of the global oceanic circulation accountable for widespread ocean stratification and bottom anoxia processes in deep oceanic settings and epicontinental basins. In agreement with very negative oxygen isotope values measured on fossil shells from the NW Tethys, our simulations also show that recurrent discharges of brackish and nutrient-rich Arctic surface waters through the Viking Corridor could have led to both vertical and geographical gradients in salinity and seawater $\delta^{18} \mathrm{O}$ in the NW Tethyan seas. Locally contrasted conditions in water mass density and rises in productivity rates due to strong nutrient supplies could partly explain the regional severity of the anoxic event in the restricted Euro-boreal domains, as it has been previously suggested and modeled regionally.

Citation: Dera, G., and Y. Donnadieu (2012), Modeling evidences for global warming, Arctic seawater freshening, and sluggish oceanic circulation during the Early Toarcian anoxic event, Paleoceanography, 27, PA2211, doi:10.1029/2012PA002283.

\section{Introduction}

[2] The Early Toarcian paleoenvironmental crisis is a major event of the Jurassic characterized by profound disturbances in geochemical, sedimentary, and paleontological records [Dera et al., 2011a; Hallam and Wignall, 1997; Jenkyns et al., 2002]. It is currently believed that this event was triggered by large-scale eruptions in the Karoo-Ferrar basaltic province causing a rapid increase in atmospheric $p \mathrm{CO}_{2}$ levels and average air temperatures $\left(c a .+5^{\circ} \mathrm{C}\right)[$ Pálfy and Smith, 2000]. This rapid rise in greenhouse gas concentration is further believed to have facilitated the release of methane hydrate along continental margins and induced widespread marine anoxia [Hesselbo and Pienkowski, 2011;

\footnotetext{
${ }^{1}$ GET, UMR CNRS 5563, IRD, Université Paul Sabatier, Toulouse, France.

${ }^{2}$ LSCE, UMR CNRS 8212, CEA, Gif-sur-Yvette, France.

Corresponding author: G. Dera, GET, UMR CNRS 5563, IRD, Université Paul Sabatier, 14 Av. Edouard Belin, F-31400, Toulouse, France. (guillaume.dera@get.obs-mip.fr)

C2012. American Geophysical Union. All Rights Reserved.
}

Hesselbo et al., 2000; McElwain et al., 2005]. This anoxic event (known as the T-OAE) affected most marine paleoenvironments and was expressed locally by accumulations in organic matter [Baudin et al., 1990; Jenkyns, 1988; Jenkyns and Clayton, 1997; Jiménez et al., 1996]. This catastrophic disruption in paleoenvironment is also thought to have caused ocean acidification [Hermoso et al., 2012], and general reductions in neritic and pelagic carbonate productions [Bernoulli and Jenkyns, 1974; Lachkar et al., 2009; Léonide et al., 2012; Mattioli et al., 2009; Tremolada et al., 2005]. Although accurate cause-effect relationships are not yet established, these important disturbances would have caused a prominent extinction event affecting marine and continental faunas all over the world as well as profound changes in the spatial distribution of species [Caswell et al., 2009; Cecca and Macchioni, 2004; Dera et al., 2010, 2011b; Gómez and Arias, 2010; Gómez and Goy, 2011; Hallam, 1987; Harries and Little, 1999; Little and Benton, 1995; Macchioni and Cecca, 2002; Zakharov et al., 2006].

[3] For decades, the Early Toarcian global warming event has been especially well documented by $\delta^{18} \mathrm{O}$ analyses performed on belemnites, brachiopods, and fish teeth from European outcrops. The statistical analysis of current data 
show a rapid and significant decrease in $\delta^{18} \mathrm{O}$ values at the Pliensbachian-Toarcian boundary [Dera et al., 2011a], which is characterized by geographical differences in amplitudes (Figure 1). The range of isotopic shifts reach 6\%o in England and northeastern France [Dera et al., 2009b; McArthur et al., 2000], 3\% in southern Germany, Bulgaria, and Spain [Bailey et al., 2003; Gómez et al., 2008; Metodiev and Koleva-Rekalova, 2008; Rosales et al., 2004; van de Schootbrugge et al., 2005a], and 2\% in Portugal and southern France [Suan et al., 2008; van de Schootbrugge et al., 2010]. If solely linked to temperature changes, these isotopic variations would express drastic increases in surface seawater temperature (SST) exceeding more than $10^{\circ} \mathrm{C}$. Because this degree of temperature change appears unrealistic for subtropical domains, which are less prone to climatic variations than poles, additional factors linked to warmer conditions have been suggested. These include enhanced rainfall and fluvial freshwater input from surrounding continents [Bailey et al., 2003; McArthur et al., 2008; Röhl et al., 2001; Saelen et al., 1996], southward discharge of low salinity water from Arctic seas [Bjerrum et al., 2001; Hesselbo et al., 2000; Mattioli et al., 2008; van de Schootbrugge et al., 2005a], and reductions in polar ice volumes monitoring the global seawater $\delta^{18} \mathrm{O}$ values [Dera et al., 2011a; Suan et al., 2010]. Though such changes appear likely for driving regional anoxic conditions (through higher nutrient supply and salinity stratification), these hypotheses are mainly based on geochemical proxies and still remain speculative. This is mostly because they do not contain physically based models, which provide confirmation of suspected disturbances and evaluation of respective amplitudes. For the moment, only Bjerrum et al. [2001] have specifically tested the relations between global and regional water mass circulations by using a simple partly coupled ocean-atmosphere model. Consistently with the initial hypothesis of Hesselbo et al. [2000], these authors founded that when the Tethyan oceanic waters become relatively denser, strong boreal currents could flow southward in the NW Tethyan domain and locally trigger reductions in salinity. At larger scale, a better appraisal of atmospheric and oceanic processes is however of prime importance for understanding the mechanisms, which underlie the global expression of bottom anoxia in deep oceanic settings and in most epicontinental basins.

[4] Given the strong rise in atmospheric $p \mathrm{CO}_{2}$ levels during the T-OAE, the aim of this integrative study is to explore the paleoclimatic and paleoceanographic consequences of an increase in the greenhouse gas concentration during the Early Toarcian. To this end, a series of $p \mathrm{CO}_{2}$ sensitivity experiments have been carried out using a fully coupled ocean-atmosphere model. Our goal is to specify the nature of overall mechanisms linking greenhouse gas concentration, paleoclimate, and anoxia by evaluating the role of ocean-atmosphere dynamics on the disturbances recorded during this period at the global and regional scale. Furthermore we also attempt to provide clarity regarding the spatial heterogeneity of larges fluctuations in $\delta^{18} \mathrm{O}$ recorded by fossil shells from the NW Tethyan domain. For this, we address three main questions: (1) How air temperature, moisture, surface seawater temperature, and salinity evolved during the Toarcian warming event?, (2) What were the factors that governed their fluctuations?, and (3) What were the consequences for the ocean circulation dynamics?

\section{Modeling Approach}

[5] Contrarily to previous Jurassic simulations focusing either on atmospheric parameters [Chandler et al., 1992; Donnadieu et al., 2006a; Moore et al., 1992; Sellwood et al., 2000; Sellwood and Valdes, 2008; Valdes et al., 1995] or water mass circulation alone [Bjerrum et al., 2001; Cottereau and Lautenschlager, 1994], our approach is based on a fully coupled model, namely the Fast Ocean-atmosphere Model (FOAM), which considers the global interactions between the atmosphere and ocean dynamics. It combines a low spectral resolution R15 (48 × 40 grid) atmosphere model counting 18 altimetric levels with a highly efficient mediumresolution $(128 \times 128$ grid $)$ ocean module composed by 24 bathymetric levels. FOAM successfully simulates many aspects of the present-day climate and compares well with other contemporary medium-resolution climate models. It was previously used to investigate numerous past climate changes, ranging from the Neoproterozoic glaciations to the Holocene variations [Donnadieu et al., 2006b; Huynh and Poulsen, 2005; Liu et al., 2003; Poulsen et al., 2001].

[6] The continental distribution used for experiments derives from the Early Jurassic paleogeographic reconstruction of R. Blakey (http://cpgeosystems.com) (Figure 2). Given the importance of the sea level rise during the Early Toarcian [Hallam, 1981, 1997, 2001], the Viking and Hispanic corridors were slightly enlarged for allowing surface water exchanges between the NW Tethyan, Arctic, and Panthalassan seas. Even if their precise opening times and depths remain controversial (especially for the Hispanic Corridor), it is generally suspected that these epicontinental seaways were already sufficiently deep for allowing the migration of ammonites, bivalves, ostracods, foraminifers or dinoflagellates in the middle of the Early Jurassic [Aberhan, 2001, 2002; Arias, 2006; Dera et al., 2011b; Hallam, 1977; Mattioli et al., 2008; Nikitenko, 2008; van de Schootbrugge et al., 2005a; Venturi et al., 2006]. Also, the NW Tethyan paleogeography was simplified to few emerged lands owing to the limitation in resolution imposed by the oceanic model. For the same reasons but also for uncertainty problems, spatial disparities in basinal depth were not considered for the NW Tethyan seas. Even if these details as well as the location of sills may influence the local circulation patterns in high-resolution models [Bjerrum et al., 2001], we consider that the consequences are negligible at the scale of our medium-resolution oceanic grid. Consequently, we assume a mean depth of $-200 \mathrm{~m}$ for European basins and all epicontinental shelves, a gradual transition for the oceanic slope, and a flat bottom bathymetry of $-4500 \mathrm{~m}$ for deep oceans. Similarly to GCM simulations of Sellwood et al. [2000] and consistently with the lack of major plate collision during the Jurassic, a maximum elevation of $2000 \mathrm{~m}$ is ascribed to the main mountain chains. Finally, boundary conditions were completed by calculating a reduction of $-1.53 \%$ in the solar constant relative to the present-day value (i.e., 1344.07 against 1365 W.m ${ }^{-2}$ ) [Gough, 1981], and by applying the present-day orbital parameters.

[7] In order to simulate the Early Toarcian warming event, we ran the model at three different atmospheric $p \mathrm{CO}_{2}$ levels. 

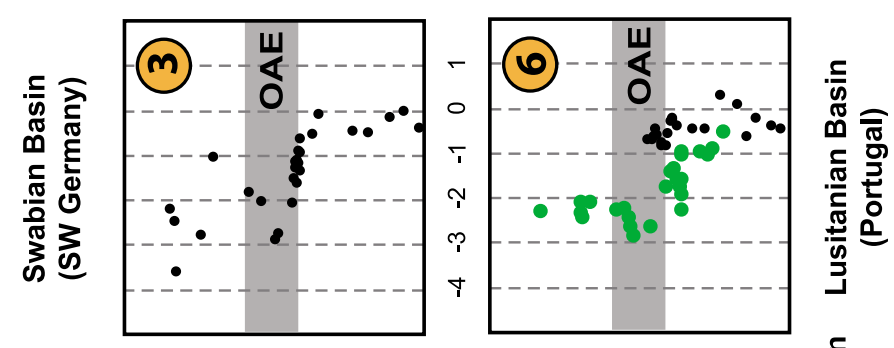

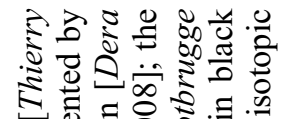

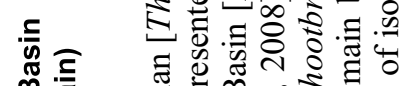
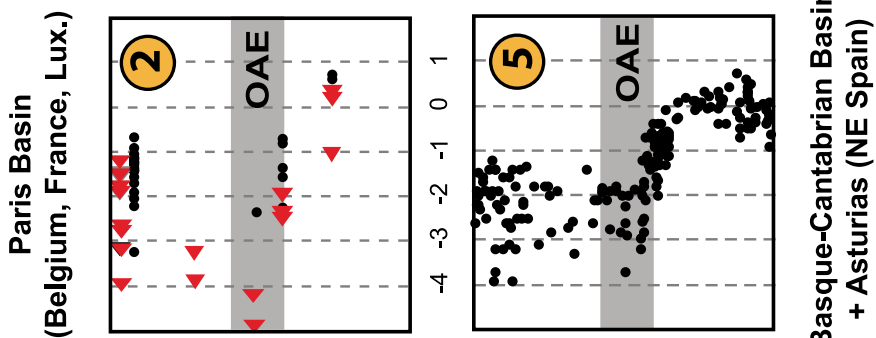

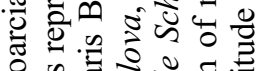

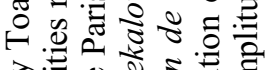

글류

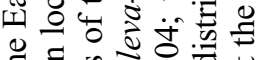

ฮี

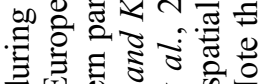
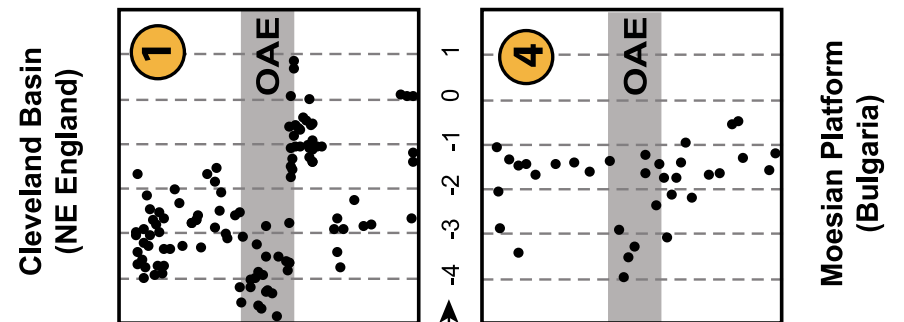

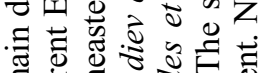

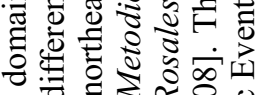

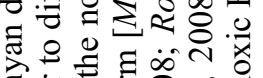

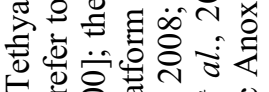

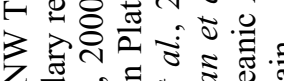

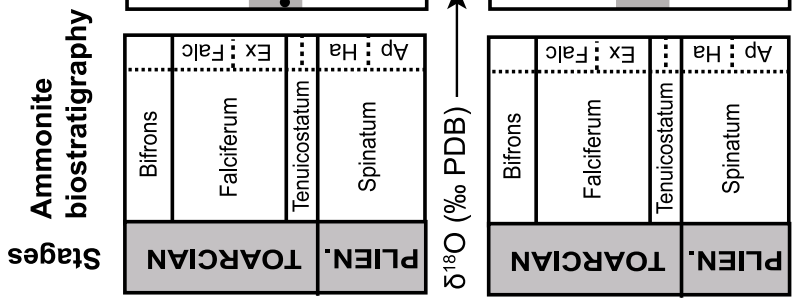

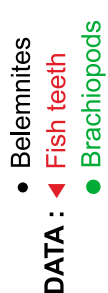

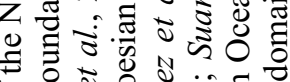

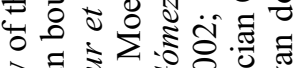

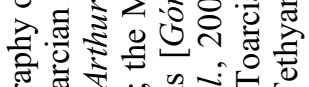

कृ

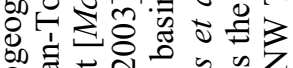

0.

ڤ.

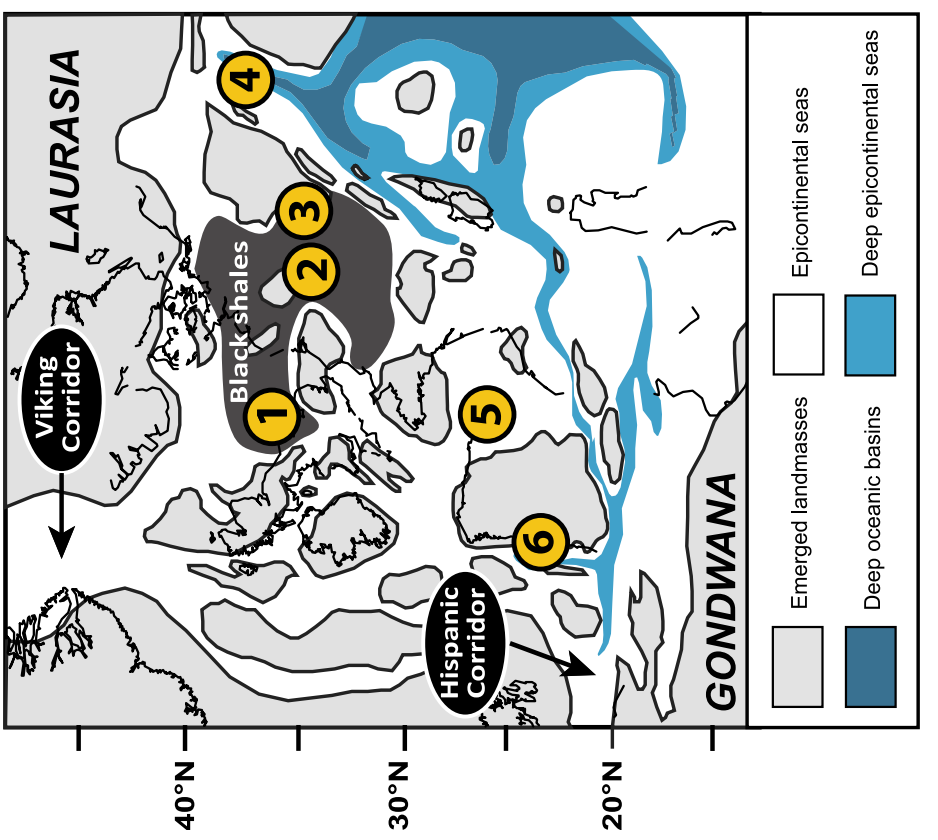

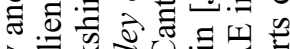

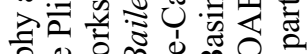

त्ज़ڤ

. एँ

焉焉

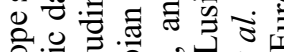

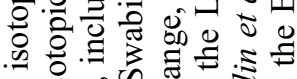

10 की

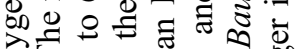

○ें

. 용 \&े

-

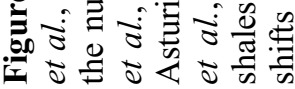




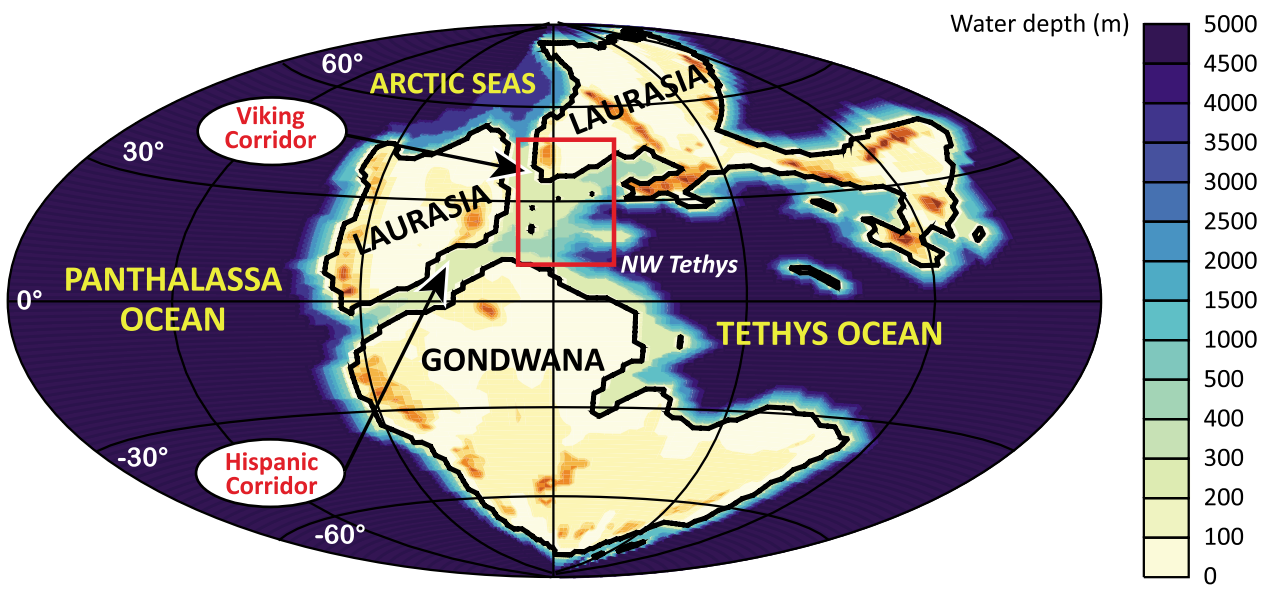

Figure 2. Paleogeographical boundary conditions used for modeling experiments (modified from the Early Jurassic representation of R. Blakey: http://cpgeosystems.com). The red rectangle represents the NW Tethyan area that is further detailed in Figure 9.

Consistently with $p \mathrm{CO}_{2}$ values inferred from stomatal indexes measured by McElwain et al. [2005], atmospheric $\mathrm{CO}_{2}$ concentrations were set to $2 \times, 4 \times$, and $6 \times$ the preindustrial level (i.e., 560, 1120, 1680 ppm). These three successive atmospheric $p \mathrm{CO}_{2}$ levels are expected to capture the paleoclimatic changes ranging from the cool Late Pliensbachian period to the Early Toarcian thermal optimum. The experiments were integrated for 1000 years without flux corrections or deep ocean acceleration. During the last 100 years of model integration, there is no apparent drift in the upper ocean (between the surface and $300 \mathrm{~m}$ depth), and $<0.001^{\circ} \mathrm{C} /$ year change in globally averaged ocean temperature.

\section{Results and Discussion}

\subsection{Influences of $p \mathrm{CO}_{2}$ Levels on the Toarcian Paleoclimate}

[8] Whatever the $p \mathrm{CO}_{2}$ levels estimated for the Pliensbachian-Toarcian transition, it is noteworthy that the latitudinal distribution of annually averaged air temperatures inferred from simulations appears more equable than for the present-day (Figure 3a). Interestingly we observe, on the one hand, extended subtropical areas with annual air temperature of 20 to $30^{\circ} \mathrm{C}$ up to $40^{\circ}$ latitude (especially for the $4 \times$ and $6 \times$ experiments), and cold to temperate subpolar climates characterized by annual temperatures of -10 to $5^{\circ} \mathrm{C}$ on the other. Though heavily contrasted, these results fully agree with previous Jurassic temperature patterns modeled by Donnadieu et al. [2009] and Sellwood and Valdes [2008], although their simulations relied on GCMs neglecting deep ocean circulation effects. Our results are also particularly compatible with the current databases of paleobotanical, paleontological, and sedimentary proxies available for the Early Jurassic, which indicate both globally extended subtropical climatic belts and cold to temperate biomes toward the higher latitudes [Hallam, 1984, 1985, 1993; Rees et al., 2000; Ziegler et al., 1993, 2004].

[9] Our experiments also show that, by assuming a tripling of $p \mathrm{CO}_{2}$ levels during the Early Toarcian, the average global air temperature increases by $+4.5^{\circ} \mathrm{C}$, ranging from $15.5^{\circ} \mathrm{C}$ at
$2 \times \mathrm{CO}_{2}$ to $20^{\circ} \mathrm{C}$ at $6 \times \mathrm{CO}_{2}$ (Figure $3 \mathrm{a}$ ). These results are greater than previous estimates $\left(+3^{\circ} \mathrm{C}\right)$ based on simple thermodynamic relationships between $p \mathrm{CO}_{2}$ values and temperature [Beerling and Brentnall, 2007]. Our GCM simulations consequently reveal the importance of feedback processes on the modulation of global temperatures. Toward the high latitudes, the air heating exceeds $+10^{\circ} \mathrm{C}$ owing to reductions in ice cover and albedo, which amplify the mechanism (Figure 4a). Such a drastic heating in subpolar areas is corroborated by substantial paleofloristic reorganizations in the Siberian area characterized by northward dispersals of thermophylous ferns and gymnosperms of Euro-Sinian origin [Zakharov et al., 2006]. In the southern hemisphere, similar plant turnovers have been documented in continental deposits from eastern Australia, with relative rises in the abundance of Araucarian and Podocarp conifers typical of more temperate domains (see Turner et al. [2009] for a review). In the midlatitudes and tropical domains, the magnitude of the warming event appears much lower and reaches $+5^{\circ} \mathrm{C}$ and $+3^{\circ} \mathrm{C}$ respectively. Nevertheless, this climate change seems to have been strong enough to trigger major modifications in the southern Laurasian vegetation, as documented by the increasing domination of Cheirolepidiaceans and subtropical ferns in western Chinese basins [Wang et al., 2005]. Importantly, this latitudinal heterogeneity in air heating is very coherent with previous experiments simulating an increase of $\sim 1000 \mathrm{ppm}$ during the Late Triassic and Middle Cretaceous [Huynh and Poulsen, 2005; Poulsen et al., 2007].

[10] In parallel to the global warming event, our simulation results reveal that successive rises in $p \mathrm{CO}_{2}$ during the Early Toarcian drove a slight increase of $+9 \mathrm{~cm} /$ year in the global precipitation rates (Figure 3b). This rise is marked by a global redistribution of net moisture (i.e., precipitation minus evaporation rates) over lands and seas (Figure 4b). At $6 \times \mathrm{CO}_{2}$, high latitudes and most equatorial regions of Gondwana and Tethys get substantially more humid, with precipitations rates regionally rising by +10 to $+20 \mathrm{~cm} /$ year. Likely marked by amplifications of strong monsoonal events typical of Pangean supercontinents [Chandler et al., 1992; Kutzbach and Gallimore, 1989; Loope et al., 2001; Parrish 

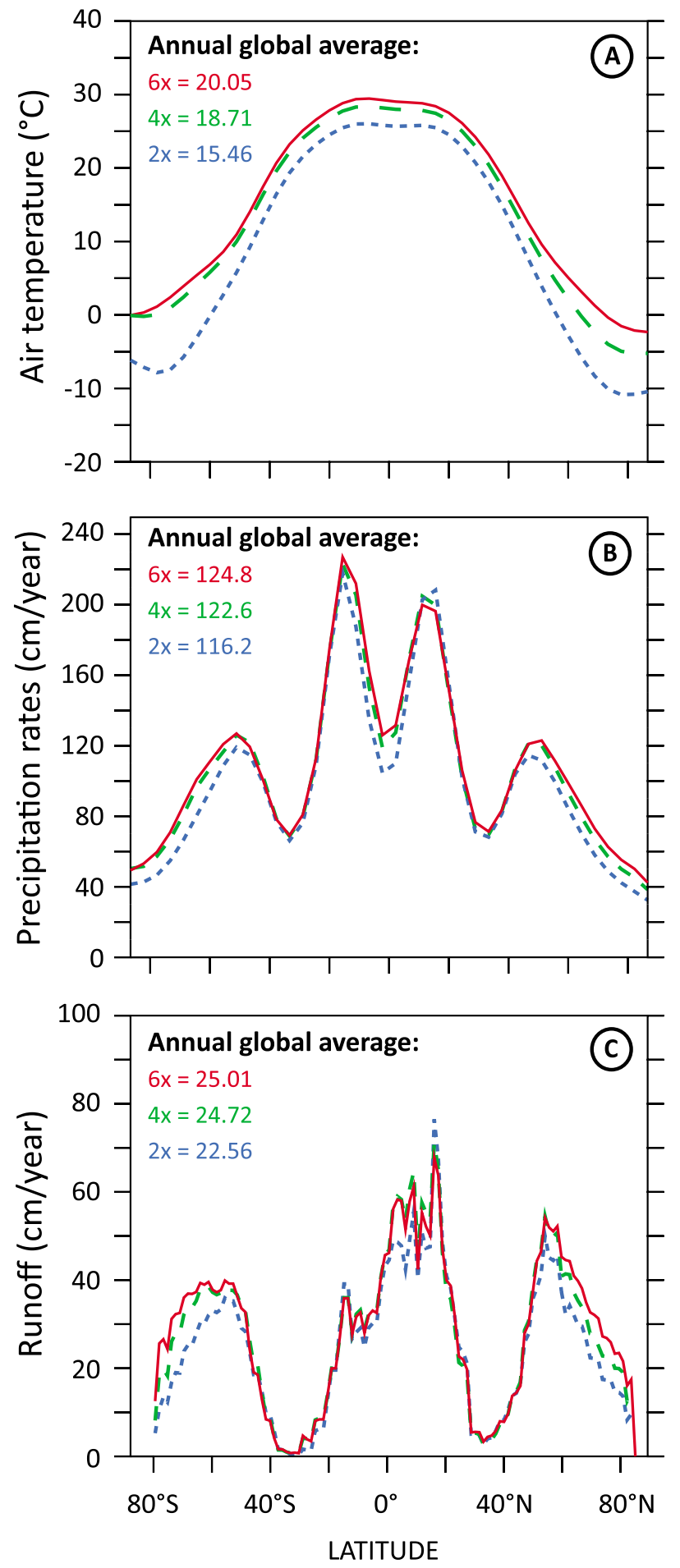

Figure 3. Latitudinal distribution of zonally averaged annual (a) air temperatures, (b) precipitation rates, and (c) continental runoff during the Early Toarcian warming event. Results are displayed for $2 \times, 4 \times$, and $6 \times$ experiments. Note that all parameters markedly increase toward the high latitudes when the $p \mathrm{CO}_{2}$ increases.

and Peterson, 1988], these regional changes involve a stronger runoff on the boreal landmasses such as the FennoScandian and Siberian shields, as well as on the northwestern and southern parts of the Gondwanan continent
(Figures $3 \mathrm{c}$ and $4 \mathrm{c}$ ). Consistently with our results showing global rises of $+3.5 \mathrm{~cm} /$ year in the mean annual continental runoff (locally ranging from -20 to $+25 \mathrm{~cm} /$ year), stronger weathering rates of continental crusts are confirmed by independent geological proxies. These latter include excursions toward more radiogenic values of strontium and osmium isotopes [Cohen et al., 2002], higher kaolinite contents in marine sediments deposited close to Euro-boreal landmasses [Dera et al., 2009a], or thick detrital deposits and important phosphorus influxes from northwestern margins of Gondwana [Bodin et al., 2010]. Conversely, the eastern parts of the Panthalassan Ocean and the marine periTethyan margins get substantially drier at $6 \times \mathrm{CO}_{2}$ (Figure $4 b$ ). In details, evaporation rates would have been markedly higher over the marine Mediterranean areas of the Tethyan domain during the Early Toarcian warming event (i.e., on the eastern Maghrebian margins of Gondwana). To our knowledge, no sedimentological feature currently proves such a regional rise in aridity at this time. It is probably because the sea level was too elevated for recording obvious evaporation indexes [Hallam, 1981, 1997, 2001]. Nevertheless, it is worth noting that regional evaporite deposits and carbonate platforms were very common at times of lower sea level as in the preceding Sinemurian and Pliensbachian periods [Rees et al., 2000; Ziegler et al., 2004]. Also, the atmospheric GCM simulations of Chandler et al. [1992] and Sellwood and Valdes [2008] confirm the presence of a seasonally dry climate over this marine domain during the Early and Late Jurassic. Consequently, we suggest that the marine Mediterranean domain could well have been particularly prone to high evaporation rates all over the Jurassic and more especially during the Toarcian and Late Oxfordian-Early Tithonian climatic optimums [Dera et al., 2011a].

\subsection{Arctic Seawater Warming and Freshening}

[11] Along with air temperature patterns, our modeling approach shows that the evolution of surface seawater temperatures was zonally heterogeneous across the globe (Figures 5a and 6a). Based on model considerations, SSTs increased by +2 to $+3.5^{\circ} \mathrm{C}$ in subtropical domains, testifying that variations calculated from $\delta^{18} \mathrm{O}$ values (i.e., exceeding $+10^{\circ} \mathrm{C}$ ) may be strongly overestimated for the Tethyan seas. However, seawater temperatures could have gained $+8^{\circ} \mathrm{C}$ to the poles, so that the sea ice formation could have been importantly impacted (Figure 6b). In agreement with occurrences of glendonites and exotic boulders in Late Pliensbachian sediments from northern Siberia [Rogov and Zakharov, 2010; Suan et al., 2011], our simulations attest that at $2 \times \mathrm{CO}_{2}$, and in a context of reduced solar constant, the temperature of polar surface seawater could have reached 0 to $-2^{\circ} \mathrm{C}$. This would then allow the formation of an extended sea ice volume, stretching south to $\sim 60^{\circ}$ latitude, prior to the well-known global warming event. These cold to freezing seawater conditions could well have been favorable to the first emergence of endemic Jurassic ammonites species in the Arctic province [Dera et al., 2011b]. During the subsequent rise in SST, our simulations show that the annual sea ice extension decreased by half at $4 \times \mathrm{CO}_{2}$ then $90 \%$ at $6 \times \mathrm{CO}_{2}$ (Figure 6b). This change could have led to important disturbances in the Arctic biota, as reflected by strong biotic turnovers and regional migration events [Dera et al., 

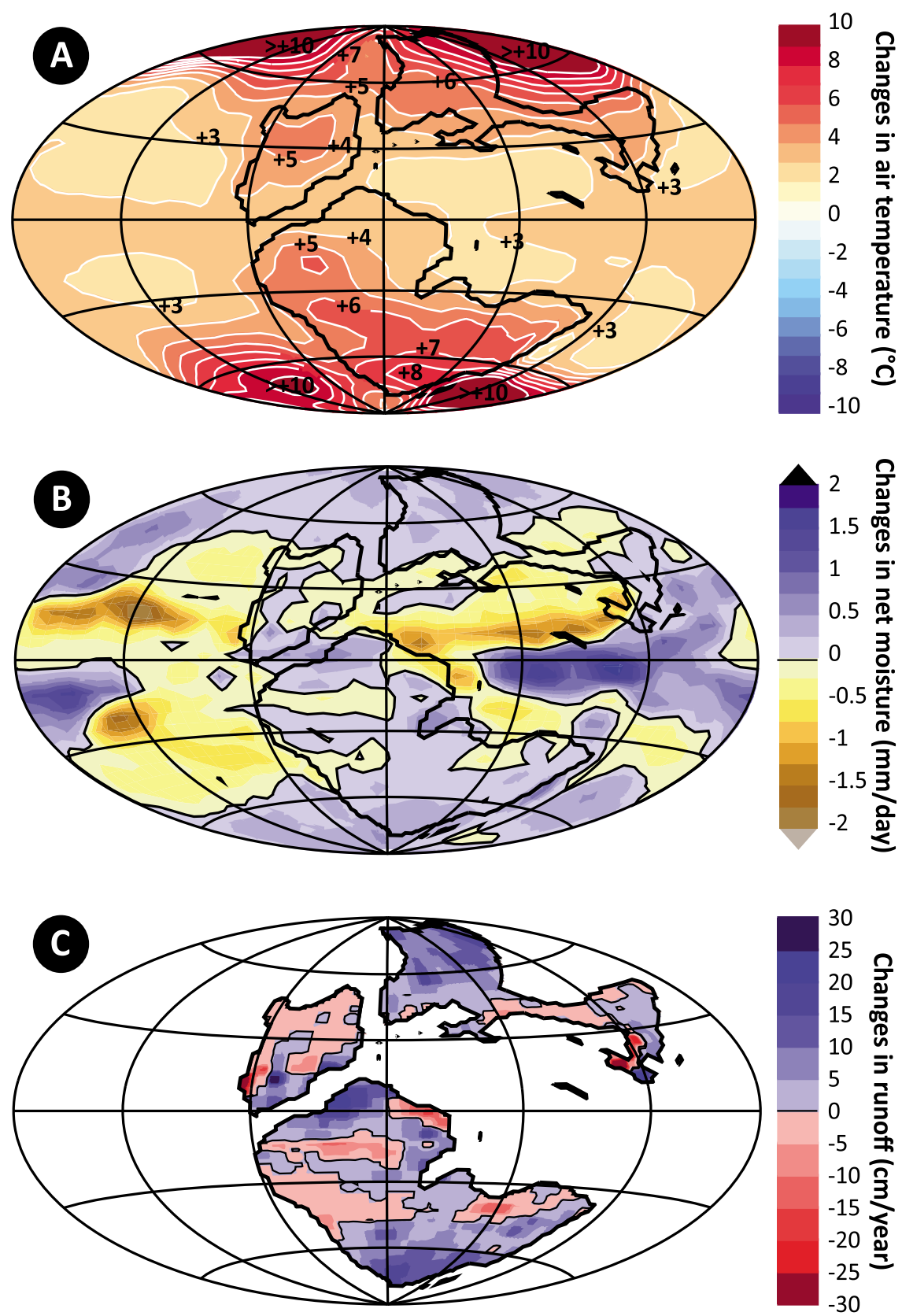

Figure 4. Simulations of global paleoclimatic changes during the Early Toarcian warming event. The results present the spatial differences in (a) air temperature, (b) net moisture, and (c) runoff between the $6 \times$ and $2 \times$ experiments. Note the spatial heterogeneity of changes marked by strong rises in temperature, precipitation rates, and runoff on high-latitude landmasses.

2010, 2011b; Nikitenko and Mickey, 2004; Nikitenko and Shurygin, 1992; Suan et al., 2011; Zakharov et al., 2006]. Nevertheless, this does not give evidence for waxing and waning of large ice volumes on continents leading to strong decreases in seawater $\delta^{18} \mathrm{O}$ values. Recently, simulations have shown that small Jurassic ice sheets were possible over boreal uplands but that extended ice caps likely occurred when $p \mathrm{CO}_{2}$ dropped below $400 \mathrm{ppm}$ or at times of minimal seasonal forcing [Donnadieu et al., 2011; Valdes et al., 1995]. Given the slightly higher $p \mathrm{CO}_{2}$ levels estimated by McElwain et al. [2005] and in a context of relatively temperate polar climates, we suggest that demises of partial continental ice sheets formed during the Late Pliensbachian cooling event likely involved minor variations in seawater $\delta^{18} \mathrm{O}$ values (below $0.5 \%$ ).

[12] In conjunction with regionally higher evaporation rates, our simulations show that the Early Toarcian warming event involved a slight rise in surface salinity in most subtropical and midlatitude seas, with regional maximums of variations reaching +1 to $+2 \mathrm{psu}$ in the Mongol-Okhotsk Ocean (i.e., northeast of Laurasia) and in the southwestern part of Gondwana (Figures 5b and 6c). Conversely, a striking surface water freshening locally reaching -6 psu occurred in the Arctic seas, with average regional decreases in salinity 

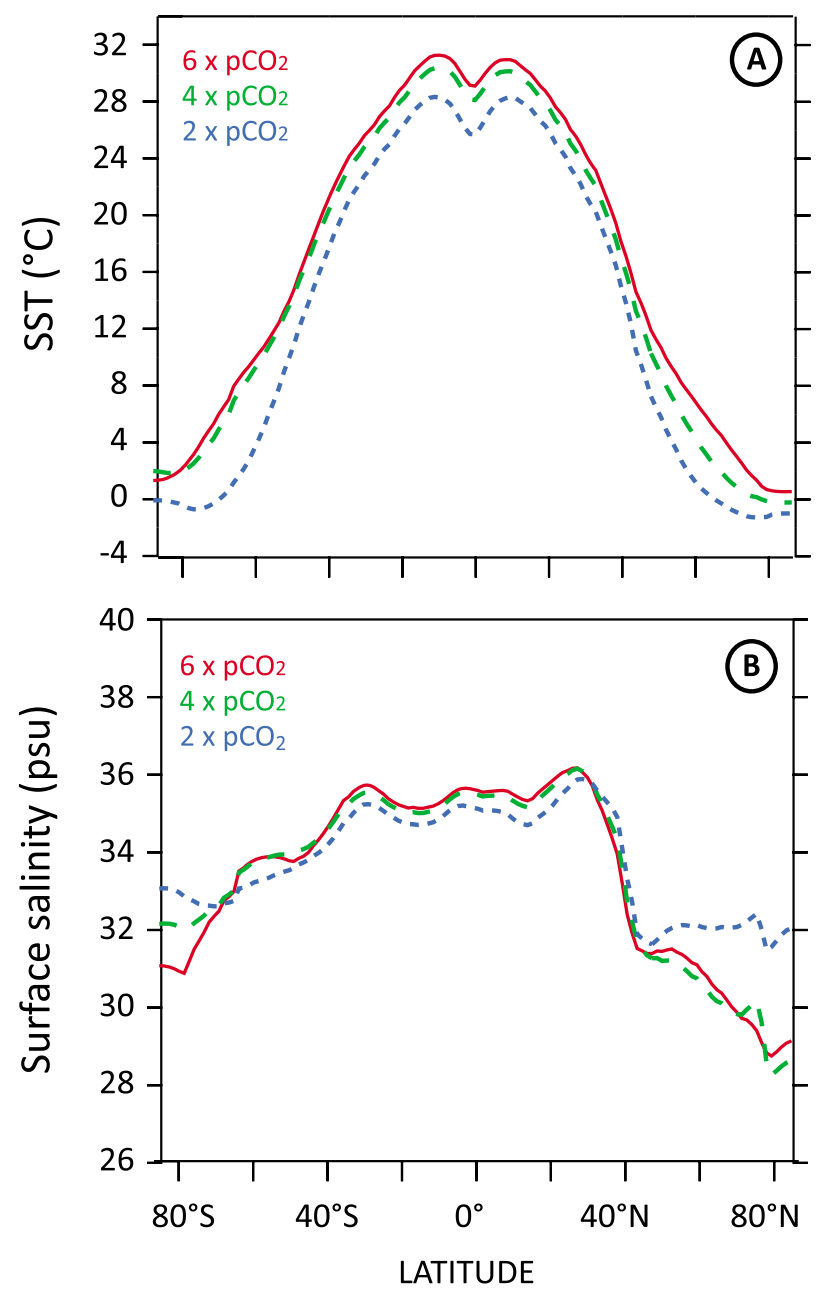

Figure 5. Latitudinal distribution of zonally averaged (a) annual SST and (b) surface seawater salinity during the Early Toarcian warming event. Results are displayed for $2 \times, 4 \times$, and $6 \times$ experiments. Note that, when the $\mathrm{CO}_{2}$ concentration increases, SST markedly increases toward the high latitudes, whereas the surface salinity inversely decreases (especially in the Arctic basin).

from 32 to 28 psu. To our knowledge, this major regional event, affecting Arctic surface waters, remains difficult to confirm. This is because there is a lack of geochemical and geological salinity proxies from boreal outcrops [Nikitenko and Shurygin, 1992; Suan et al., 2011]. Nevertheless, it is worth mentioning that compared to benthic and nektobenthic faunas, the extinction rates of marine organisms inhabiting surface to intermediates waters such as ammonites were slightly higher in the Arctic seas than in the NW Tethyan domains [Dera et al., 2010]. Also, this high-latitude freshening process seems realistic as it occurred with stronger amplitudes during the PETM and the warm Eocene "Azolla event" [Brinkhuis et al., 2006; Cope and Winguth, 2011; Roberts et al., 2009]. Similarly, the regional drop in salinity would be influenced by multiple factors, including a rapid thaw of polar sea ice volumes under warmer conditions, strong fluvial discharges from the Siberian and FennoScandian shields, and a paleogeographical restriction of the Arctic basin preventing important mixing with salty Panthalassan waters.

\subsection{Oceanic Circulation Slowdown During the T-OAE}

[13] Whatever the $p \mathrm{CO}_{2}$ levels used for sensitivity experiments, our Early Jurassic simulations show that the global surface ocean circulation was quite symmetrical between the two hemispheres (Figure 7a). The main simulated features consist in: 1) strong equatorial currents flowing westward in the Tethyan and Panthalassan oceans, drifting along the northern Gondwanan margin, then passing through the Hispanic Corridor; and 2) two large Panthalassan subtropical gyres with respectively clockwise and anticlockwise rotations in the northern and southern hemispheres. These global results confirm the paleobiogeographically and physically based conceptual model of Arias [2008] for the Early Jurassic. Also, they are very consistent with previous ocean circulation patterns based on Permian or idealized Pangean continental configurations [Kutzbach et al., 1990; Winguth et al., 2002]. The only difference concerns the velocity of surface currents, which could have been markedly more vigorous in the southern hemisphere than to the North during the Permian [Winguth et al., 2002]. Excepting potential model dependences, we suggest that this divergence could be linked to the relatively more polar position of Gondwana at the end of the Paleozoic.

[14] Under low atmospheric $\mathrm{CO}_{2}$ concentrations and lower derived temperatures (i.e., during the spinatum ammonite zone), our results indicate that the subtropical Panthalassan currents drifting along the eastern shelves of Laurasia and Gondwana followed extended poleward convections in the two hemispheres. By cooling, these salty currents then sank toward the bottom to the contact of highlatitude sea ice. This density-related process is reflected in profound mixed layer depths in the Arctic and southwestern parts of the Panthalassan Ocean (Figure 7b), inducing strong and symmetrical meridional overturning circulations in the two hemispheres (Figure 8). Importantly, this corroborates previous Pangean simulations based on similar landmass configurations and low $p \mathrm{CO}_{2}$ levels [Huynh and Poulsen, 2005; Kutzbach et al., 1990; Smith et al., 2004]. Conjointly with higher oxygen solubility rates in cold waters [Weiss, 1970], this mechanism likely ensured an efficient water mass oxygenation during the Late Pliensbachian cooling event, which preceded the massive release of greenhouse gas [Suan et al., 2010]. Indeed, a good ventilation of bottom seawater is supported in the NW Tethyan basins by low organic matter accumulations and abundant bioturbation features in shallow paleoenvironments during the spinatum ammonite zone [Röhl et al., 2001; SchmidRöhl et al., 2002] and also by high diversification rates of macro- and microorganisms inhabiting different parts of the water column [Dera et al., 2010; Hallam, 1987; van de Schootbrugge et al., 2005a]. Moreover, Hori [1997] interpreted the presence of hematite-bearing bedded cherts in Japanese outcrops as a proof of oxidizing conditions in deep oceanic waters of Panthalassa before the T-OAE.

[15] During the Early Toarcian warming event, the freshening of surface Arctic seawaters drove major changes in the global ocean dynamics marked by a reorganization of surface circulation patterns (Figure 7). Similarly to processes 

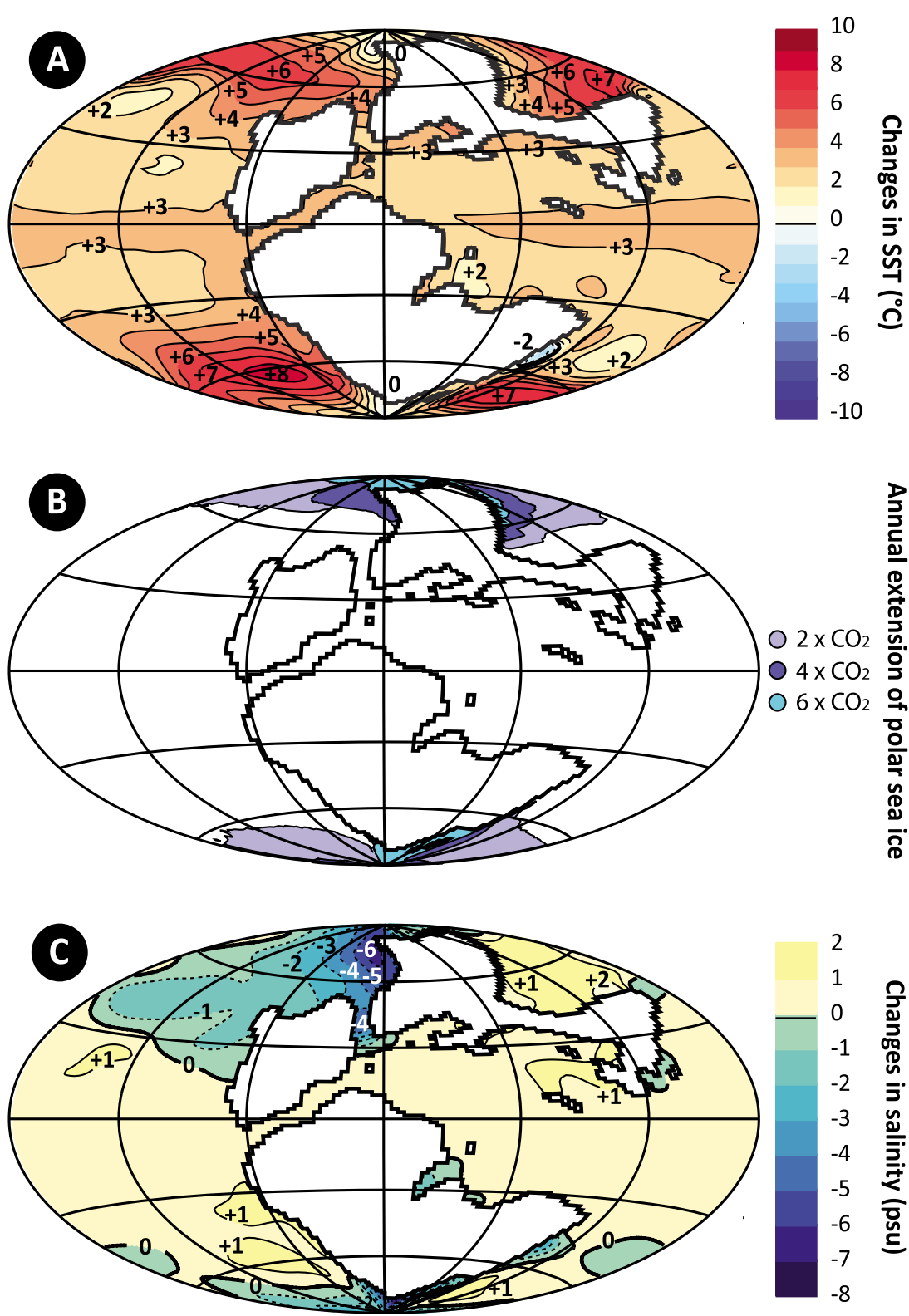

Figure 6. Simulations of global paleoceanographic changes during the Early Toarcian warming event. The spatial differences in (a) SST and (c) surface seawater salinity between the $6 \times$ and $2 \times$ experiments are shown. (b) Annual sea ice extensions for the $2 \times, 4 \times$, and $6 \times$ experiments. Note that rises in $\mathrm{CO}_{2}$ concentrations drive heating and freshening of Arctic seawaters as well as progressive demises of polar sea ices.

suggested in the Arctic seas during the PETM or the ongoing warming event [Aagaard and Carmack, 1989; Cope and Winguth, 2011], regional changes in water mass density stopped the northward meridional convection and reduced the sinking of salty subtropical Panthalassan currents in the Arctic area, retrospectively reinforcing the surface water freshening processes and warming of deep waters. As previously suggested by Schmidt and Mysak [1996] as well as Bjerrum et al. [2001], this regional change in deep-water formation was partly compensated by higher mixing rates in the southern hemisphere, and to a lesser extent in the southern Asian areas of the subtropical Tethyan domain (Figure 7b). More surprising, we note that for the $4 \times$ and $6 \times$ experiments, the mixed layer depth appears slightly deeper in the European basins. This would suggest a good ventilation of the water column during the T-OAE, which seems quite contrary to the setting of anoxic events in the NW Tethys. However, it is imperative that we note that this local simulated pattern should be regarded with caution. This is primarily because our simulations rely on a homogeneous epicontinental bathymetry of $-200 \mathrm{~m}$, which neglects the presence and the role of shallow silled Euro-boreal basins promoting water mass restriction [McArthur et al., 2008]. Nevertheless, Trabucho-Alexandre et al. [2012] recently demonstrated that the conditions of organic matter accumulations would have been markedly variable in the NW 

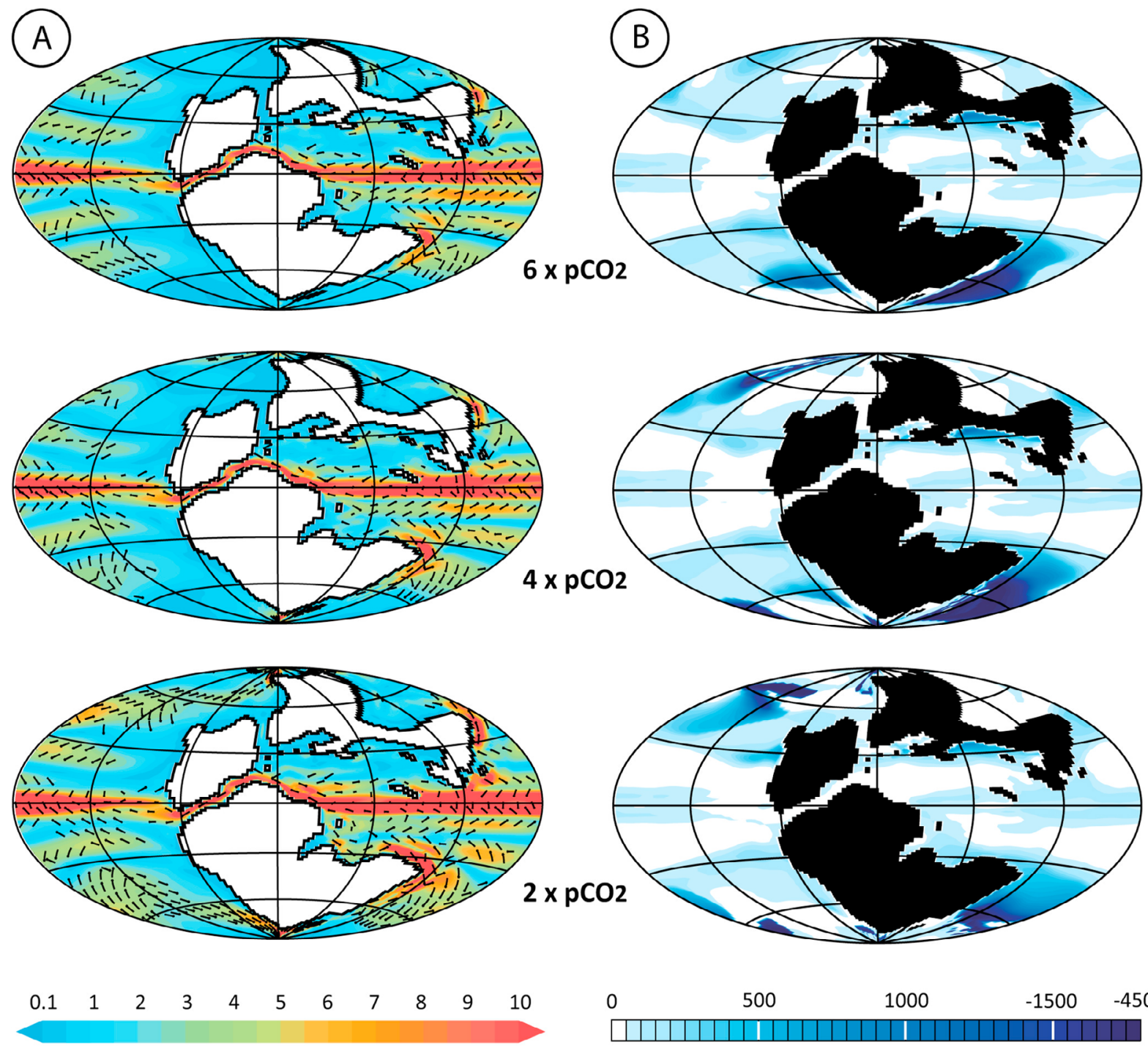

\section{Oceanic current velocity at $-150 \mathrm{~m}(\mathrm{~cm} / \mathrm{s})$}

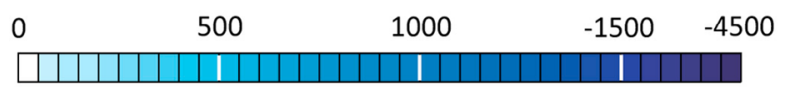

\section{Mixed layer depth (m)}

Figure 7. Simulations of global ocean circulation patterns during the Early Toarcian warming event with (a) maps representing the direction and velocity of main currents at $-150 \mathrm{~m}$ of depth and (b) maps of mixed layer depths showing areas where the surface currents sink toward the bottom. Results are displayed for the $2 \times, 4 \times$, and $6 \times$ experiments. Note that under low $p \mathrm{CO}_{2}$ levels, the Panthalassan currents have an extended poleward convection, which allows the formation of deep waters in the Arctic and southern Panthalassan oceans. When the $p \mathrm{CO}_{2}$ levels increase, the thermohaline circulation is disturbed by changes in water mass density, which stop the meridional convection and the sinking of Arctic waters.

Tethys, and regionally monitored by very high productivity rates in contexts of highly dynamic energetic conditions.

[16] At global scale, the polar disturbances in water mass conditions caused a substantial reduction in the global ocean meridional overturning circulation characterized a progressive disruption in the symmetrical mixing patterns between the two hemispheres (Figure 8). Importantly, this sluggish thermohaline circulation is in agreement with radiolarian orientations measured in Jurassic cherts from Japan, which suggest a long-term decrease in the deep Panthalassan current velocity from the Pliensbachian to the Toarcian [Dozen and Ishiga, 1997]. Also, these results are very coherent with $p \mathrm{CO}_{2}$ sensitivity experiments performed for the previous Late Triassic warming event [Huynh and Poulsen, 2005]. Nevertheless, it is worth noting that for other periods like the Late Permian, GCM simulations show that massive rises in atmospheric $\mathrm{CO}_{2}$ concentrations may drive opposite mechanisms, with more vigorous and more symmetrical deep-sea circulations under warmer climates [Winguth et al., 2002; Winguth and Maier-Reimer, 2005]. This implies that simple extrapolations between high $p \mathrm{CO}_{2}$ levels, ocean dynamics, and OAE may be avoided, because the paleogeographical context may have a paramount influence. 

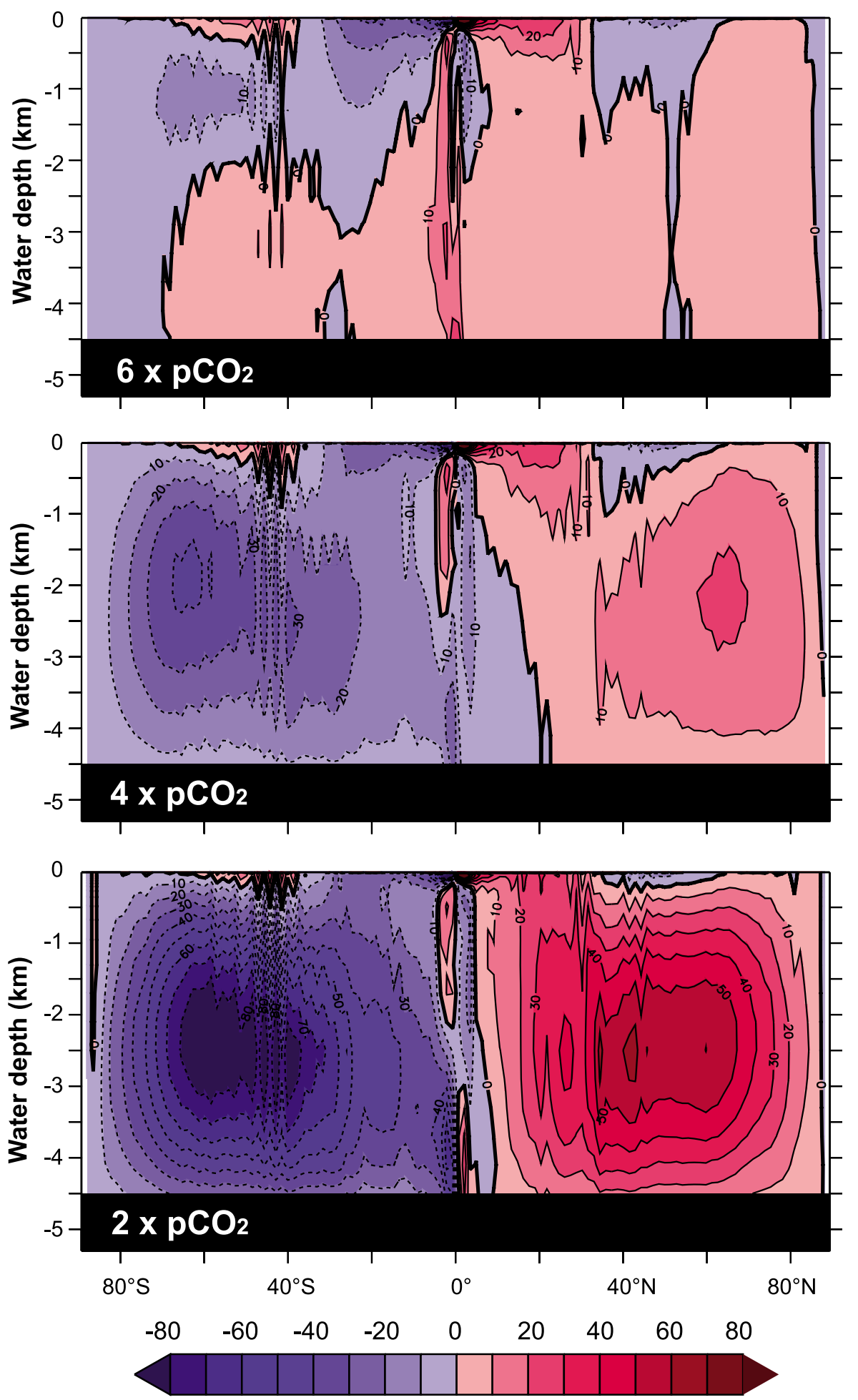

\section{Global meridional overturning circulation (in Sverdrup: $10^{6} \mathrm{~m}^{3} \mathrm{~s}^{-1}$ )}

Figure 8. Latitudinal and bathymetric representations of the global meridional ocean overturning circulation (in Sverdrups: $10^{6} \mathrm{~m}^{3} \mathrm{~s}^{-1}$ ) for the $2 \times, 4 \times$, and $6 \times$ experiments. Positive values (red with solid lines) indicate clockwise flows, and negative values (blue with dashed lines) indicate counterclockwise flows. Note that the meridional overturning circulation is substantially reduced when atmospheric $p \mathrm{CO}_{2}$ levels increase and nearly disappears in the $6 \times$ experiment. 


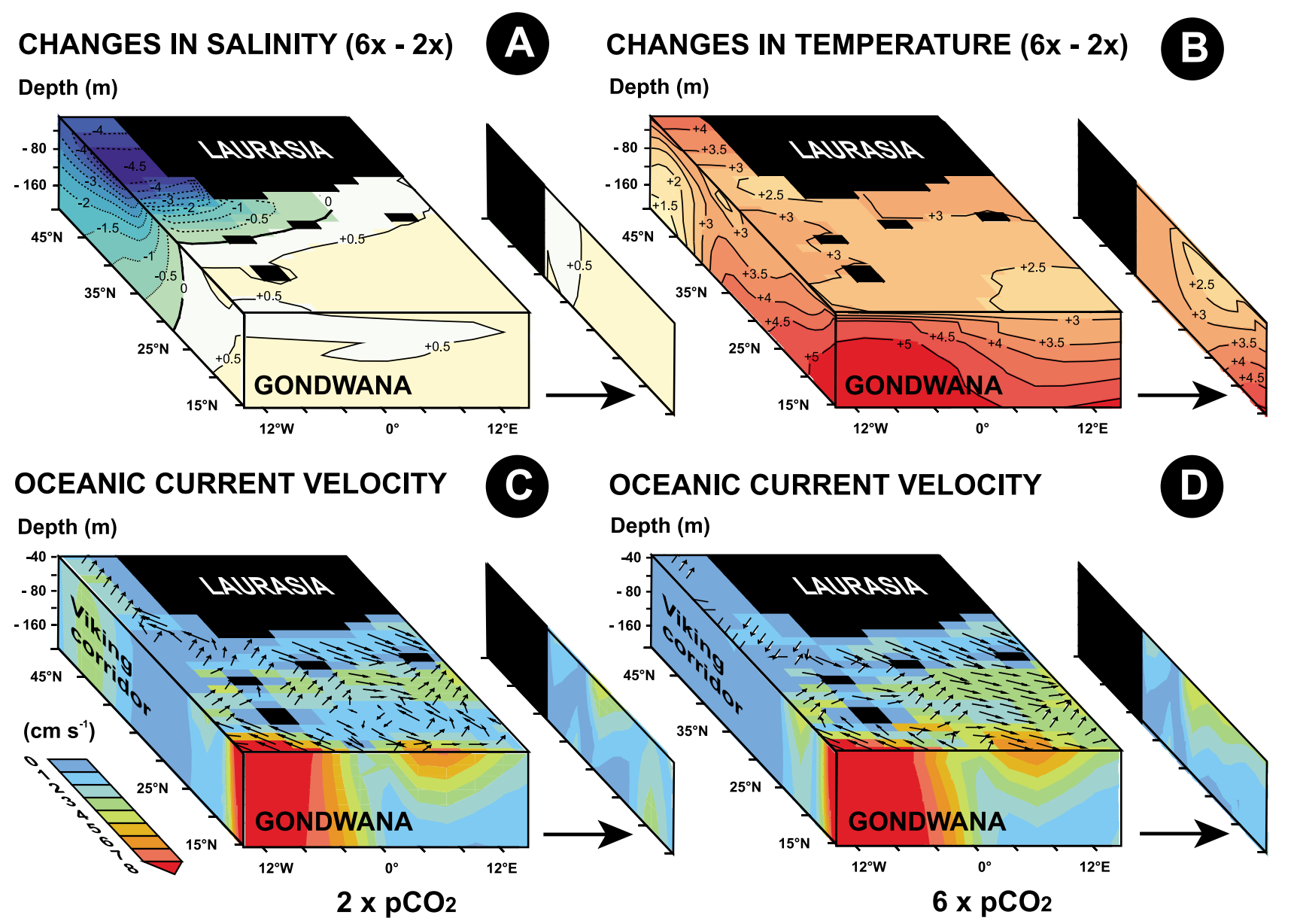

Figure 9. Simulations of NW Tethyan changes in (a) salinity, (b) SST, and (c and d) oceanic circulation patterns during the Early Toarcian warming event. The studied area crosses the Viking Corridor to the West and the borders the Gondwanan shelf to the South. Simulations shown in Figures 9a and 9b are expressed by the differences between the $6 \times$ and $2 \times$ experiments, whereas those presented in Figures 9c and $9 \mathrm{~d}$, respectively, correspond to the $2 \times$ and $6 \times$ experiments. Note that, under high $\mathrm{CO}_{2}$ concentrations, the salinity decreases in basins influenced by discharges from the Viking Corridor and SST especially increases in the southwestern part of the NW Tethyan domain. This heterogeneity could be linked to a strengthening of warm Tethyan currents drifting along the Gondwanan margins.

\subsection{Consequences on the NW Tethyan Seas}

[17] As discussed above, our results show that SSTs increase by +2 to $+3.5^{\circ} \mathrm{C}$ in most epicontinental basins of the NW Tethys (Figure 9b). The only exception concerns a rise of $+5^{\circ} \mathrm{C}$ in deeper waters $(-100$ to $-200 \mathrm{~m})$ of southwestern seas approximately corresponding to the present Lusitanian Basin. As revealed by circulation patterns (Figures 7a, 9c, and 9d), this thermal anomaly is probably related to a strengthening of warm equatorial Tethyan currents drifting along the northern Gondwanan margins. Furthermore, the drift of these currents through westernmost areas and their subsequent clockwise rotation due to southward-directed boreal flows is coherent with neodymium isotope data [Dera et al., 2009b], as well as ammonite and nannofossil migration routes evidenced for the Early Toarcian [Dera et al., 2011b; Reggiani et al., 2010]. Based on $6 \times$ experiment results (Figure 9d), it is also likely that more vigorous NW Tethyan currents would account for major disruptions in faunal provincialism and the celebrated northward expansion of marine Mediterranean faunas at the beginning of the Toarcian [Arias and Whatley, 2005; Dera et al., 2011b; Macchioni and Cecca, 2002; Vörös, 2002].

[18] However, the spatial distribution of rises in SST simulated during the Toarcian warming event is in disagreement with available $\delta^{18} \mathrm{O}$ data. Our synthesis of available geochemical data show that shifts in oxygen isotopes, recorded at the onset of the T-OAE (Figure 1), decrease less significantly in sedimentary basins that are geographically outside of the western Boreal domain. This is especially obvious in the Lusitanian and Grand Causses basins, which are adjacent to the Mediterranean domain. Our results provide further evidence suggesting that these sorts of oceanic changes may greatly complicate the paleoclimatic interpretation of $\delta^{18} \mathrm{O}$ data and refute an exclusive and straightforward thermal interpretation of isotopic records [Bailey et al., 2003; Dera et al., 2009b; Saelen et al., 1996; van de Schootbrugge et al., 2005a]. Conversely, the observed oxygen isotope gradient is more consistent with regional influxes of brackish seawaters from Arctic seas through the Viking 
Corridor (Figure 9a). According to our simulations, these southward-directed currents were probably driven by strong water density gradients and local basinal configurations, which may have reduced the salinity of adjacent seas by -1 to $-5 \mathrm{psu}$ at the surface. Our global modeling approach is consistent with the hypothesis of Hesselbo et al. [2000] and the regional simulations of Bjerrum et al. [2001], and further contradicts the direct influence of strong freshwater influxes from boreal landmasses at this time [Bailey et al., 2003; Röhl et al., 2001; Saelen et al., 1996].

[19] As our model does not use isotope fractionation modules, it remains difficult to directly evaluate the oxygen isotope composition of Arctic waters and their impact on $\delta^{18} \mathrm{O}$ values recorded by the Tethyan fossils. Nevertheless, several modeling studies have shown that during periods of high atmospheric $p \mathrm{CO}_{2}$ levels, offsets of 2 to $6 \%$ may occur between polar and subtropical seawater $\delta^{18} \mathrm{O}$ values [Roche et al., 2006; Tindall et al., 2010]. As these estimates correspond to the range of observed $\delta^{18} \mathrm{O}$ variations in the Early Toarcian, discharges of brackish Arctic waters with lower $\delta^{18} \mathrm{O}$ values appears as a plausible scenario for explaining both the strong amplitude and the latitudinal gradient of $\delta^{18} \mathrm{O}$ changes recorded by fossils in the NW Tethys. Of course, this hypothesis should be tested with an appropriate model in a next step.

\subsection{Implications for Anoxia Processes}

[20] In the general debate on the spatiotemporal distribution of past oceanic anoxic events in Earth's history [Jenkyns, 2010], the global extent of the T-OAE is currently highly questioned [McArthur et al., 2008; van de Schootbrugge et al., 2005b; Wignall et al., 2005]. Indeed, most available anoxia and euxinia proxies such as black shales with high TOC values [Baudin et al., 1990], low ichnofabric indexes [Röhl et al., 2001], pyrite framboids [Wignall et al., 2005], positive excursions in $\delta^{13} \mathrm{C}$ and $\delta^{15} \mathrm{~N}$ [Hesselbo et al., 2007; Jenkyns and Clayton, 1997; Jenkyns et al., 2001], biomarkers [van Breugel et al., 2006], or new isotopic and elemental signals [Hermoso et al., 2009; McArthur et al., 2008; Newton et al., 2011; Nielsen et al., 2011; Tribovillard et al., 2011] come from relatively restricted European basins corresponding to former seaways of the NW Tethyan domain. However, well-laminated deposits locally characterized by higher organic contents and coeval with the prominent negative $\delta^{13} \mathrm{C}$ excursion have been recently identified in South America, Siberia, Tibet, Canada, and Japan [Al-Suwaidi et al., 2010; Caruthers et al., 2011; Izumi et al., 2012; Suan et al., 2011; Wignall et al., 2006]. Even if their interpretation still remains debated, this indicate that hypoxic to euxinic epicontinental conditions could have regionally prevailed all over the world during the Early Toarcian warming event [Jenkyns 1988], but with strong differences in intensity. Furthermore, the discovery of organic carbon enrichments and pyrite framboids in Japanese cherts corresponding to deep oceanic deposits of Panthalassa suppose that anoxic conditions likely reached deep ocean settings [Gröcke et al., 2011; Hori, 1997; Wignall et al., 2010]. Recently, Gill et al. [2011] confirmed this hypothesis by demonstrating that, according to box-modeling approaches, the burial of pyrite in the NW Tethyan domain alone could not account for the general positive $\delta^{34} \mathrm{~S}$ excursions reported during the T-OAE. In this context, it may be supposed that anoxic conditions reached numerous epicontinental shelves and some deep oceanic basins. Nevertheless, a worldwide extension of lethal conditions affecting the whole water column seems quite unrealistic.

[21] Our coupled ocean-atmosphere modeling approach provides a reliable scenario for explaining the synchronous setting of bottom anoxic conditions in both deep oceanic and epicontinental seas, as well as their spatial differences in intensity. Our model shows that the Early Toarcian warming event and the resulting changes in polar water mass density and temperature triggered a general slowdown in the thermohaline circulation. It is likely that this global disturbance accounted for a strong decrease in the water column mixing, resulting in oxygen depletions in most bottom paleoenvironments. However, additional factors to water mass stratification such as global increases in nutrient supply, lower oxygen solubility in warmer waters, and basinal restrictions cannot be excluded and it is likely they acted in combination during past OAEs [Jenkyns, 2010; McArthur et al., 2008; Meyer and Kump, 2008]. For example, the conjunction of additional adverse circumstances could explain the regional severity of anoxic events in the NW Tethys. According to our results and high-resolution simulations of Bjerrum et al. [2001], we suggest that recurrent discharges of colder, nutrient-rich, and freshened Arctic seawater through the Viking Corridor could have facilitated local water mass stratifications and increased productivity rates in the Euroboreal basins. Compared to shallow or open marine paleoenvironments of the Mediterranean area, this regional severity in anoxic to euxinic conditions is actually reflected in higher organic contents [Baudin et al., 1990] as well as stronger extinction rates in the north-European basins [Dera et al., 2010]. Also, it is clear that a strong restriction of northern basins was a major parameter for enhancing these disturbances [McArthur et al., 2008].

\section{Conclusion}

[22] Our simulations show that massive rises in atmospheric $\mathrm{CO}_{2}$ concentrations triggered major ecological disturbances during the T-OAE. Conjointly with an average global warming event of $+4.5^{\circ} \mathrm{C}$, the demise of polar sea ice and stronger high-latitude continental runoff rates could have freshened the Arctic surface seawaters, resulting in a thermohaline circulation collapse. This disruption was likely accountable for global bottom anoxia processes both in epicontinental seaways and deep oceanic settings. Influxes of boreal brackish seawaters through the Viking Corridor probably influenced the spatial disparity of $\delta^{18} \mathrm{O}$ variations recorded in the NW Tethyan domain and drastically strengthened regional productivity rates, water mass stratification, and anoxic conditions. Finally, our coupled modeling approach show that the rise in SST was heterogeneous across the globe and would have not exceeded +2 to $+5^{\circ} \mathrm{C}$ in subtropical seas, attesting that changes inferred from $\mathrm{NW}$ Tethyan $\delta^{18} \mathrm{O}$ variations may be highly biased by changes in salinity and circulation patterns.

[23] Acknowledgments. We acknowledge V. Lefebvre, A. C. Chaboureau, and P. Sepulchre for the valuable technical assistance during the modeling work. We thank C. Bjerrum and B. van de Schootbrugge for their constructive and helpful reviews, as well as A. Caruthers for fruitful 
discussions and comments on the manuscript. The ANR Project Phylospace funded this work.

\section{References}

Aagaard, K., and E. C. Carmack (1989), The role of sea ice and other fresh water in the Arctic circulation, J. Geophys. Res., 94, 14,485-14,498, doi:10.1029/JC094iC10p14485.

Aberhan, M. (2001), Bivalve palaeobiogeography and the Hispanic Corridor: Time of opening and effectiveness of a proto-Atlantic seaway, Palaeogeogr. Palaeoclimatol. Palaeoecol., 165, 375-394, doi:10.1016/ S0031-0182(00)00172-3.

Aberhan, M. (2002), Opening of the Hispanic Corridor and the Early Jurassic bivalve biodiversity, in Palaeobiogeography and Biodiversity Change: The Ordovician and Mesozoic-Cenozoic Radiations, edited by J. A. Crame and A. W. Owen, Geol. Soc. Spec. Publ., 194, 127-139, doi:10.1144/GSL.SP.2002.194.01.10.

Al-Suwaidi, A. H., et al. (2010), First record of the Early Toarcian Oceanic Anoxic Event from the Southern Hemisphere, Neuquen Basin, Argentina, J. Geol. Soc., 167, 633-636, doi:10.1144/0016-76492010-025.

Arias, C. (2006), Northern and Southern Hemispheres ostracod palaeobiogeography during the Early Jurassic: Possible migration routes, Palaeogeogr. Palaeoclimatol. Palaeoecol., 233, 63-95, doi:10.1016/j. palaeo.2005.09.006.

Arias, C. (2008), Palaeoceanography and biogeography in the Early Jurassic Panthalassa and Tethys Oceans, Gondwana Res., 14, 306-315, doi:10.1016/j.gr.2008.03.004.

Arias, C., and R. C. Whatley (2005), Palaeozoogeography of Western European Lower Jurassic (Pliensbachian and Toarcian) Ostracoda Geobios, 38, 697-724, doi:10.1016/j.geobios.2002.10.001.

Bailey, T. R., et al. (2003), Paleoceanographic changes of the Late Pliensbachian-Early Toarcian interval: A possible link to the genesis of an Oceanic Anoxic Event, Earth Planet. Sci. Lett., 212, 307-320, doi:10.1016/S0012-821X(03)00278-4.

Baudin, F., et al. (1990), Mapping and geochemical characterization of the Toarcian organic-matter in the Mediterranean Tethys and Middle-East, Org. Geochem., 16, 677-687, doi:10.1016/0146-6380(90)90109-D.

Beerling, D. J., and S. J. Brentnall (2007), Numerical evaluation of mechanisms driving Early Jurassic changes in global carbon cycling, Geology, 35, 247-250, doi:10.1130/G23416A.1.

Bernoulli, D., and H. Jenkyns (1974), Alpine, Mediterranean and North Atlantic Mesozoic facies in relation to the early evolution of the Tethys, in Modern and Ancient Geosynclinal Sedimentation, edited by R. H. Dott Jr. and R. H. Shaver, Spec. Publ. SEPM Soc. Sediment. Geol., 19, 129-160.

Bjerrum, C. J., F. Surlyk, J. H. Callomon, and R. L. Slingerland (2001), Numerical paleoceanographic study of the Early Jurassic Transcontinental Laurasian Seaway, Paleoceanography, 16, 390-404, doi:10.1029/ 2000PA000512.

Bodin, S., et al. (2010), Toarcian carbon isotope shifts and nutrient changes from the Northern margin of Gondwana (High Atlas, Morocco, Jurassic): Palaeoenvironmental implications, Palaeogeogr. Palaeoclimatol. Palaeoecol., 297, 377-390, doi:10.1016/j.palaeo.2010.08.018.

Brinkhuis, H., et al. (2006), Episodic fresh surface waters in the Eocene Arctic Ocean, Nature, 441, 606-609, doi:10.1038/nature04692.

Caruthers, A. H., et al. (2011), The significance of an Early Jurassic (Toarcian) carbon-isotope excursion in Haida Gwaii (Queen Charlotte Islands), British Columbia, Canada, Earth Planet. Sci. Lett., 307, 19-26, doi:10.1016/j.epsl.2011.04.013.

Caswell, B. A., et al. (2009), New range data for marine invertebrate species across the early Toarcian (Early Jurassic) mass extinction, J. Geol. Soc., 166, 859-872, doi:10.1144/0016-76492008-0831.

Cecca, F., and F. Macchioni (2004), The two Early Toarcian (Early Jurassic) extinction events in ammonoids, Lethaia, 37, 35-56, doi:10.1080/ 00241160310008257.

Chandler, M. A., et al. (1992), Pangean climate during the Early Jurassic: GCM simulations and the sedimentary record of paleoclimate, Geol. Soc. Am. Bull., 104, 543-559, doi:10.1130/0016-7606(1992)104<0543: PCDTEJ $>2.3 . \mathrm{CO} ; 2$.

Cohen, A. S., et al. (2002), Isotopic and geochemical evidence for changes in global weathering during the Toarcian OAE, Geochim. Cosmochim. Acta, 66, A147-A147.

Cope, J. T., and A. M. E. Winguth (2011), On the sensitivity of ocean circulation to arctic freshwater input during the Paleocene/Eocene Thermal Maximum, Palaeogeogr. Palaeoclimatol. Palaeoecol., 306, 82-94, doi:10.1016/j.palaeo.2011.03.032.

Cottereau, N., and M. Lautenschlager (1994), Tethyan oceanic circulations during the Latest Jurassic: A GCM simulation, C. R. Acad. Sci., Ser. IIa 318, 389-396.
Dera, G., et al. (2009a), Distribution of clay minerals in Early Jurassic Peritethyan seas: Palaeoclimatic significance inferred from multiproxy comparisons, Palaeogeogr. Palaeoclimatol. Palaeoecol., 271, 39-51, doi:10.1016/j.palaeo.2008.09.010.

Dera, G., et al. (2009b), Water mass exchange and variations in seawater temperature in the NW Tethys during the Early Jurassic: Evidence from neodymium and oxygen isotopes of fish teeth and belemnites, Earth Planet. Sci. Lett., 286, 198-207, doi:10.1016/j.epsl.2009.06.027.

Dera, G., et al. (2010), High-resolution dynamics of Early Jurassic marine extinctions: The case of Pliensbachian-Toarcian ammonites (Cephalopoda), J. Geol. Soc., 167, 21-33, doi:10.1144/0016-76492009-068.

Dera, G., et al. (2011a), Climatic ups and downs in a disturbed Jurassic world, Geology, 39, 215-218, doi:10.1130/G31579.1.

Dera, G., et al. (2011b), Ammonite paleobiogeography during the Pliensbachian-Toarcian crisis (Early Jurassic) reflecting paleoclimate, eustasy, and extinctions, Global Planet. Change, 78, 92-105, doi:10.1016 j.gloplacha.2011.05.009.

Donnadieu, Y., Y. Goddéris, R. Pierrehumbert, G. Dromart, F. Fluteau, and R. Jacob (2006a), A GEOCLIM simulation of climatic and biogeochemical consequences of Pangea breakup, Geochem. Geophys. Geosyst., 7, Q11019, doi:10.1029/2006GC001278.

Donnadieu, Y., et al. (2006b), Modelling the primary control of paleogeography on Cretaceous climate, Earth Planet. Sci. Lett., 248, 426-437, doi:10.1016/j.epsl.2006.06.007.

Donnadieu, Y., et al. (2009), Exploring the climatic impact of the continental vegetation on the Mesozoic atmospheric $\mathrm{CO}_{2}$ and climate history, Clim. Past, 5, 85-96, doi:10.5194/cp-5-85-2009.

Donnadieu, Y., G. Dromart, Y. Goddéris, E. Pucéat, B. Brigaud, G. Dera, C. Dumas, and N. Olivier (2011), A mechanism for brief glacial episodes in the Mesozoic greenhouse, Paleoceanography, 26, PA3212, doi:10.1029/2010PA002100.

Dozen, K., and H. Ishiga (1997), Estimation of current velocity and direction from orientation of conical radiolarians in Lower Jurassic bedded cherts from Southwest Japan: Indications of eddy-driven sedimentation, Mar. Micropaleontol., 30, 197-214, doi:10.1016/S0377-8398(96) 00022-9.

Gill, B. C., et al. (2011), A global perturbation in the sulfur cycle during the Toarcian Oceanic Anoxic event, Earth Planet. Sci. Lett., 312, 484-496, doi:10.1016/j.epsl.2011.10.030.

Gómez, J. J., and C. Arias (2010), Rapid warming and ostracods mass extinction at the Lower Toarcian (Jurassic) of central Spain, Mar. Micropaleontol., 74, 119-135, doi:10.1016/j.marmicro.2010.02.001.

Gómez, J. J., and A. Goy (2011), Warming-driven mass extinction in the Early Toarcian (Early Jurassic) of northern and central Spain. Correlation with other time-equivalent European sections, Palaeogeogr. Palaeoclimatol. Palaeoecol., 306, 176-195, doi:10.1016/j.palaeo.2011.04.018.

Gómez, J. J., et al. (2008), Seawater temperature and carbon isotope variations in belemnites linked to mass extinction during the Toarcian (Early Jurassic) in Central and Northern Spain. Comparison with other European sections, Palaeogeogr. Palaeoclimatol. Palaeoecol., 258, 28-58, doi:10.1016/j.palaeo.2007.11.005.

Gough, D. O. (1981), Solar interior structure and luminosity variations, Sol. Phys., 74, 21-34, doi:10.1007/BF00151270.

Gröcke, D. R., et al. (2011), An open ocean record of the Toarcian oceanic anoxic event, Solid Earth, 2, 245-257, doi:10.5194/se-2-245-2011.

Hallam, A. (1977), Biogeographic evidence bearing on creation of Atlantic seaways in Jurassic, J. Paleontol., 51, 12-13.

Hallam, A. (1981), A revised sea-level curve for the Early Jurassic, J. Geol. Soc., 138, 735-743, doi:10.1144/gsjgs.138.6.0735.

Hallam, A. (1984), Continental humid and arid zones during the Jurassic and Cretaceous, Palaeogeogr. Palaeoclimatol. Palaeoecol., 47, 195-223, doi:10.1016/0031-0182(84)90094-4.

Hallam, A. (1985), A review of Mesozoic climates, J. Geol. Soc., 142, 433-445, doi:10.1144/gsjgs.142.3.0433.

Hallam, A. (1987), Radiations and extinctions in relation to environmental change in the marine Jurassic of north west Europe, Paleobiology, 13, $152-168$.

Hallam, A. (1993), Jurassic climates as inferred from the sedimentary and fossil record, Philos. Trans. R. Soc. London B, 341, 287-296, doi:10.1098/rstb.1993.0114

Hallam, A. (1997), Estimates of the amount and rate of sea-level change across the Rhaetian-Hettangian and Pliensbachian-Toarcian boundaries (latest Triassic to early Jurassic), J. Geol. Soc., 154, 773-779, doi:10.1144/gsigs. 154.5.0773.

Hallam, A. (2001), A review of broad pattern of the Jurassic sea-level changes and their possible causes in the light of current knowledge, Palaeogeogr. Palaeoclimatol. Palaeoecol., 167, 23-37, doi:10.1016/ S0031-0182(00)00229-7. 
Hallam, A., and P. B. Wignall (1997), Mass Extinctions and Their Aftermath, 320 pp., Oxford Univ. Press, Oxford, U. K.

Harries, P. J., and C. T. S. Little (1999), The early Toarcian (Early Jurassic) and the Cenomanian-Turonian (Late Cretaceous) mass extinctions: Similarities and contrasts, Palaeogeogr. Palaeoclimatol. Palaeoecol., 154, 39-66, doi:10.1016/S0031-0182(99)00086-3.

Hermoso, M., F. Minoletti, L. Le Callonnec, H. C. Jenkyns, S. P. Hesselbo, R. E. M. Rickaby, M. Renard, M. de Rafélis, and L. Emmanuel (2009), Global and local forcing of Early Toarcian seawater chemistry: A comparative study of different paleoceanographic settings (Paris and Lusitanian basins), Paleoceanography, 24, PA4208, doi:10.1029/2009PA001764.

Hermoso, M., et al. (2012), Dynamics of a stepped carbon-isotope excursion: Ultra high-resolution study of Early Toarcian environmental change, Earth Planet. Sci. Lett., 319-320, 45-54, doi:10.1016/j. epsl.2011.12.021

Hesselbo, B., and G. Pienkowski (2011), Stepwise atmospheric carbonisotope excursion during the Toarcian Oceanic Anoxic Event (Early Jurassic, Polish Basin), Earth Planet. Sci. Lett., 301, 365-372, doi:10.1016/j.epsl.2010.11.021

Hesselbo, S. P., et al. (2000), Massive dissociation of gas hydrate during a Jurassic oceanic anoxic event, Nature, 406, 392-395, doi:10.1038/ 35019044

Hesselbo, S. P., et al. (2007), Carbon-isotope record of the Early Jurassic (Toarcian) Oceanic Anoxic Event from fossil wood and marine carbonate (Lusitanian Basin, Portugal), Earth Planet. Sci. Lett., 253, 455-470, doi:10.1016/j.epsl.2006.11.009.

Hori, R. S. (1997), The Toarcian radiolarian event in bedded cherts from southwestern Japan, Mar. Micropaleontol., 30, 159-169, doi:10.1016/ S0377-8398(96)00024-2.

Huynh, T. T., and C. J. Poulsen (2005), Rising atmospheric $\mathrm{CO}_{2}$ as a possible trigger for the end-Triassic mass extinction, Palaeogeogr. Palaeoclimatol. Palaeoecol., 217, 223-242, doi:10.1016/j.palaeo.2004.12.004.

Izumi, K., et al. (2012), Early Toarcian (Early Jurassic) oceanic anoxic event recorded in the shelf deposits in the northwestern Panthalassa: Evidence from the Nishinakayama Formation in the Toyora area, west Japan, Palaeogeogr. Palaeoclimatol. Palaeoecol., 315-316, 100-108, doi:10.1016/j.palaeo.2011.11.016

Jenkyns, H. C. (1988), The Early Toarcian (Jurassic) anoxic event Stratigraphy, sedimentary, and geochemical evidence, Am. J. Sci., 288, 101-151, doi:10.2475/ajs.288.2.101.

Jenkyns, H. C. (2010), Geochemistry of oceanic anoxic events, Geochem. Geophys. Geosyst., 11, Q03004, doi:10.1029/2009GC002788.

Jenkyns, H. C., and C. J. Clayton (1997), Lower Jurassic epicontinental carbonates and mudstones from England and Wales: Chemostratigraphic signals and the early Toarcian anoxic event, Sedimentology, 44, 687-706, doi:10.1046/j.1365-3091.1997.d01-43.x.

Jenkyns, H. C., D. R. Gröcke, and S. P. Hesselbo (2001), Nitrogen isotope evidence for water mass denitrification during the Early Toarcian (Jurassic) oceanic anoxic event, Paleoceanography, 16, 593-603, doi:10.1029/2000PA000558.

Jenkyns, H. C., et al. (2002), Chemostratigraphy of the Jurassic System: Applications, limitations and implications for palaeoceanography, J. Geol. Soc., 159, 351-378, doi:10.1144/0016-764901-130.

Jiménez, A. P., et al. (1996), The Early Toarcian anoxic event in the westernmost Tethys (Subbetic): Paleogeographic and paleobiogeographic significance, J. Geol., 104, 399-416, doi:10.1086/629836.

Kutzbach, J. E., and R. G. Gallimore (1989), Pangean climates: Megamonsoons of the megacontinent, J. Geophys. Res., 94, 3341-3357, doi:10.1029/JD094iD03p03341

Kutzbach, J. E., P. J. Guetter, and W. M. Washington (1990), Simulated circulation of an idealized ocean for Pangaean time, Paleoceanography, 5, 299-317, doi:10.1029/PA005i003p00299.

Lachkar, N., et al. (2009), Early Jurassic normal faulting in a carbonate extensional basin: Characterization of tectonically driven platform drowning (High Atlas rift, Morocco), J. Geol. Soc., 166, 413-430, doi:10.1144/0016-76492008-084.

Léonide, P., et al. (2012), Drowning of a carbonate platform as a precursor stage of the Early Toarcian global anoxic event (Southern Provence subBasin, South-east France), Sedimentology, 59, 156-184, doi:10.1111/ j.1365-3091.2010.01221.x.

Little, C. T. S., and M. J. Benton (1995), Early Jurassic mass extinction: A global long-term event, Geology, 23, 495-498, doi:10.1130/00917613(1995)023<0495:EJMEAG $>2.3$.CO;2.

Liu, Z., et al. (2003), Coupled climate simulation of the Evolution of global monsoons in the Holocene, J. Clim., 16, 2472-2490, doi:10.1175/1520 0442(2003)016<2472:CCSOTE $>2.0$. CO;2.

Loope, D. B., et al. (2001), Annual monsoon rains recorded by Jurassic dunes, Nature, 412, 64-66, doi:10.1038/35083554.
Macchioni, F., and F. Cecca (2002), Biodiversity and biogeography of middle-late liassic ammonoids: Implications for the early Toarcian mass extinction, Geobios, 35, suppl. 1, 165-175, doi:10.1016/S00166995(02)00057-8.

Mattioli, E., B. Pittet, G. Suan, and S. Mailliot (2008), Calcareous nannoplankton changes across the early Toarcian oceanic anoxic event in the western Tethys, Paleoceanography, 23, PA3208, doi:10.1029/ 2007PA001435.

Mattioli, E., et al. (2009), Dramatic decrease of pelagic carbonate production by nannoplankton across the Early Toarcian anoxic event (T-OAE), Global Planet. Change, 65, 134-145, doi:10.1016/j.gloplacha.2008.10.018.

McArthur, J. M., et al. (2000), Strontium isotope profile of the early Toarcian (Jurassic) oceanic anoxic event, the duration of ammonite biozones, and belemnite palaeotemperatures, Earth Planet. Sci. Lett., 179, 269-285, doi:10.1016/S0012-821X(00)00111-4.

McArthur, J. M., T. J. Algeo, B. van de Schootbrugge, Q. Li, and R. J. Howarth (2008), Basinal restriction, black shales, Re-Os dating, and the Early Toarcian (Jurassic) oceanic anoxic event, Paleoceanography, 23, PA4217, doi:10.1029/2008PA001607.

McElwain, J. C., et al. (2005), Changes in carbon dioxide during an oceanic anoxic event linked to intrusion into Gondwana coals, Nature, 435, 479-482, doi:10.1038/nature 03618 .

Metodiev, L., and E. Koleva-Rekalova (2008), Stable isotope records $\left(\delta^{18} \mathrm{O}\right.$ and $\delta^{13} \mathrm{C}$ ) of Lower-Middle Jurassic belemnites from the Western Balkan mountains (Bulgaria): Paleoenvironmental application, Appl. Geochem., 23, 2845-2856, doi:10.1016/j.apgeochem.2008.04.010.

Meyer, K. M., and L. R. Kump (2008), Oceanic euxinia in Earth history: Causes and consequences, Annu. Rev. Earth Planet. Sci., 36, 251-288, doi:10.1146/annurev.earth.36.031207.124256.

Moore, G. T., et al. (1992), Paleoclimate of the Kimmeridgian/Tithonian (Late Jurassic) world: I. Results using a general circulation model, Palaeogeogr. Palaeoclimatol. Palaeoecol., 93, 113-150, doi:10.1016 0031-0182(92)90186-9.

Newton, R. J., et al. (2011), Low marine sulfate concentrations and the isolation of the European epicontinental sea during the Early Jurassic, Geology, 39, 7-10, doi:10.1130/G31326.1.

Nielsen, S. G., et al. (2011), Thallium isotopes in early diagenetic pyrite - A paleoredox proxy?, Geochim. Cosmochim. Acta, 75, 6690-6704, doi:10.1016/j.gca.2011.07.047

Nikitenko, B. (2008), The Early Jurassic to Aalenian paleobiogeography of the Arctic realm: Implication of microbenthos (Foraminifers and Ostracodes), Stratigr. Geol. Correl., 16, 59-80.

Nikitenko, B., and M. B. Mickey (2004), Foraminifera and ostracods across the Pliensbachian-Toarcian boundary in the Arctic Realm (stratigraphy, palaeobiogeography and biofacies), in The Palynology and Micropalaeontology of Boundaries, edited by A. B. Beaudoin and M. J. Head, Geol. Soc. Spec. Publ., 230, 137-174, doi:10.1144/GSL.SP.2004.230.01.08.

Nikitenko, B. L., and B. N. Shurygin (1992), Lower Toarcian black shales and Pliensbachian-Toarcian crisis of the biota of Siberian paleoseas, paper presented at International Conference on Arctic Margins, Min. Manage. Serv., U.S. Dep. of the Interior, Anchorage, Alaska.

Pálfy, J., and P. L. Smith (2000), Synchrony between Early Jurassic extinction, oceanic anoxic event, and the Karoo-Ferrar flood basalt volcanism, Geology, 28, 747-750, doi:10.1130/0091-7613(2000)28<747:SBEJEO > 2.0.CO;2.

Parrish, J. T., and F. Peterson (1988), Wind directions predicted from global circulation models and wind directions determined from eolian sandstones of the western United States - A comparison, Sediment. Geol. 56, 261-282, doi:10.1016/0037-0738(88)90056-5.

Poulsen, C. J., R. T. Pierrehumbert, and R. L. Jacob (2001), Impact of ocean dynamics on the simulation of the neoproterozoic "snowball Earth," Geophys. Res. Lett., 28, 1575-1578, doi:10.1029/2000GL012058.

Poulsen, C. J., et al. (2007), General circulation model simulation of the $\delta^{18} \mathrm{O}$ content of continental precipitation in the middle Cretaceous: A modelproxy comparison, Geology, 35, 199-202, doi:10.1130/G23343A.1.

Rees, P. M. et al. (2000), Jurassic phytogeography and climate: New data and model comparisons, in Warm Climates in Earth History, edited by B. T. Huber, K. G. Macleod, and S. L. Wing, pp. 297-318, Cambridge Univ. Press, Cambridge, U. K., doi:10.1017/CBO9780511564512.011.

Reggiani, L., et al. (2010), Pliensbachian (Early Jurassic) calcareous nannofossils from the Peniche section (Lusitanian Basin, Portugal): A clue for palaeoenvironmental reconstructions, Mar. Micropaleontol., 75, 1-16, doi:10.1016/j.marmicro.2010.02.002.

Roberts, C. D., et al. (2009), Climate sensivity to Arctic seaway restriction during the early Paleocene, Earth Planet. Sci. Lett., 286, 576-585, doi:10.1016/j.epsl.2009.07.026.

Roche, D. M., Y. Donnadieu, E. Pucéat, and D. Paillard (2006), Effect of changes in $\delta^{18} \mathrm{O}$ content of the surface ocean on estimated sea surface 
temperatures in past warm climate, Paleoceanography, 21, PA2023, doi:10.1029/2005PA001220.

Rogov, M. A., and V. Zakharov (2010), Jurassic and Lower Cretaceous glendonite occurrences and their implication for Arctic Paleoclimate reconstructions and stratigraphy, Earth Sci. Front, 17, 345-346.

Röhl, H.-J., et al. (2001), The Posidonia Shale (Lower Toarcian) of SWGermany: An oxygen-depleted ecosystem controlled by sea level and palaeoclimate, Palaeogeogr. Palaeoclimatol. Palaeoecol., 165, 27-52, doi:10.1016/S0031-0182(00)00152-8.

Rosales, I., et al. (2004), Paleotemperature variations of Early Jurassic seawater recorded in geochemical trends of belemnites from the BasqueCantabrian basin, northern Spain, Palaeogeogr. Palaeoclimatol. Palaeoecol., 203, 253-275, doi:10.1016/S0031-0182(03)00686-2.

Saelen, G., et al. (1996), Stable-isotope analyses of Belemnite rostra from the Whitby Mudstone Fm, England: Surface water conditions during deposition of a marine black shale, Palaios, 11, 97-117, doi:10.2307/ 3515065 .

Schmid-Röhl, A., et al. (2002), Palaeoenvironmental reconstruction of Lower Toarcian epicontinental black shales (Posidonia Shale, SW Germany): Global versus regional control, Geobios, 35, 13-20, doi:10.1016/S0016-6995(02)00005-0.

Schmidt, G. A., and L. A. Mysak (1996), Can increased poleward oceanic heat flux explain the warm Cretaceous climate?, Paleoceanography, 11 , 579-593, doi:10.1029/96PA01851.

Sellwood, B. W., and P. J. Valdes (2008), Jurassic climates, Proc. Geol. Assoc., 119, 5-17, doi:10.1016/S0016-7878(59)80068-7.

Sellwood, B. W., et al. (2000), Geological evaluation of multiple general circulation model simulations of Late Jurassic palaeoclimate, Palaeogeogr Palaeoclimatol. Palaeoecol., 156, 147-160, doi:10.1016/S0031-0182(99) 00138-8

Smith, R. S., C. Dubois, and J. Marotzke (2004), Ocean circulation and climate in an idealised Pangean OAGCM, Geophys. Res. Lett., 31, L18207, doi:10.1029/2004GL020643.

Suan, G., E. Mattioli, B. Pittet, S. Mailliot, and C. Lécuyer (2008), Evidence for major environmental perturbation prior to and during the Toarcian (Early Jurassic) oceanic anoxic event from the Lusitanian Basin, Portugal, Paleoceanography, 23, PA1202, doi:10.1029/2007PA001459.

Suan, G., et al. (2010), Secular environmental precursors to Early Toarcian (Jurassic) extreme climate changes, Earth Planet. Sci. Lett., 290, 448-458, doi:10.1016/j.eps1.2009.12.047.

Suan, G., et al. (2011), Polar record of Early Jurassic massive carbon injection, Earth Planet. Sci. Lett., 312, 102-113, doi:10.1016/j.eps1.2011.09.050.

Thierry, J. et al. (2000), Middle Toarcian, in Atlas Peri-Tethys Paleogeographical Maps, edited by J. Dercourt et al., pp. 61-70, Comm. for the Geol. Map of the World, Paris.

Tindall, J., et al. (2010), Modelling the oxygen isotope distribution of ancient seawater using a coupled ocean-atmosphere GCM: Implication for reconstructing early Eocene climate, Earth Planet. Sci. Lett., 292, 265-273, doi:10.1016/j.epsl.2009.12.049.

Trabucho-Alexandre, J., et al. (2012), Toarcian black shales in the Dutch Central Graben: Record of energetic variable depositional conditions during an oceanic anoxic event, J. Sediment. Res., 82, 104-120, doi:10.2110/jsr.2012.5.

Tremolada, F., B. Van de Schootbrugge, and E. Erba (2005), Early Jurassic schizosphaerellid crisis in Cantabria, Spain: Implications for calcification rates and phytoplankton evolution across the Toarcian oceanic anoxic event, Paleoceanography, 20, PA2011, doi:10.1029/2004PA001120.

Tribovillard, N., et al. (2011), Analysis of marine environmental conditions based on molybdenum-uranium covariation - Applications to Mesozoic paleoceanography, Chem. Geol., 282, 120-130, doi:10.1016/j.chemgeo. 2011.01.015.

Turner, S., et al. (2009), Australian Jurassic sedimentary and fossil successions: Current work and future prospects for marine and non-marine correlation, GFF, 131, 49-70, doi:10.1080/11035890902924877.
Valdes, P. J., et al. (1995), Modelling Late Jurassic Milankovitch climate variations, in Orbital Forcing Timescales and Cyclostratigraphy, edited by M. R. House and A. S. Gale, Geol. Soc. Spec. Publ., 85, 115-132. van Breugel, Y., M. Baas, S. Schouten, E. Mattioli, and J. S. Sinninghe Damsté (2006), Isorenieratane record in black shales from the Paris Basin, France: Constraints on recycling of respired $\mathrm{CO}_{2}$ as a mechanism for negative carbon isotope shifts during the Toarcian oceanic anoxic event, Paleoceanography, 21, PA4220, doi:10.1029/2006PA001305.

van de Schootbrugge, B., et al. (2005a), Early Jurassic climate change and the radiation of organic-walled phytoplankton in the Tethys Ocean, Paleobiology, 31(1), 73-97, doi:10.1666/0094-8373(2005)031<0073: EJCCAT $>2.0 . \mathrm{CO} ; 2$

van de Schootbrugge, B., J. M. McArthur, T. R. Bailey, Y. Rosenthal, J. D. Wright, and K. G. Miller (2005b), Toarcian oceanic anoxic event: An assessment of global causes using belemnite $\mathrm{C}$ isotope records, Paleoceanography, 20, PA3008, doi:10.1029/2004PA001102.

van de Schootbrugge, B., et al. (2010), The enigmatic ichnofossil Tisoa siphonalis and widespread authigenic seep carbonate formation during the Late Pliensbachian in southern France, Biogeosciences, 7, 3123-3138, doi:10.5194/bg-7-3123-2010.

Venturi, F, et al. (2006), Comparison between western Tethys and eastern Pacific ammonites: Further evidence for a possible late Sinemurian-early Pliensbachian trans-Pangaean marine connection, Geol. Mag., 143 , 699-711, doi:10.1017/S0016756806002068.

Vörös, A. (2002), Victims of the Early Toarcian anoxic event: The radiation and extinction of Jurassic Koninckinidae (Brachiopoda), Lethaia, 35 345-357, doi:10.1111/j.1502-3931.2002.tb00093.x.

Wang, Y., et al. (2005), Early to Middle Jurassic vegetation and climatic events in the Qaidam Basin, northwest China, Palaeogeogr. Palaeoclimatol. Palaeoecol., 224, 200-216, doi:10.1016/j.palaeo.2005.03.035.

Weiss, R. F. (1970), The solubility of nitrogen, oxygen and argon in water and seawater, Deep Sea Res. Oceanogr. Abstr., 17, 721-735, doi:10.1016/0011-7471(70)90037-9.

Wignall, P. B., et al. (2005), The timing of paleoenvironmental change and cause-and-effect relationships during the early Jurassic mass extinction in Europe, Am. J. Sci., 305, 1014-1032, doi:10.2475/ajs.305.10.1014.

Wignall, P. B., et al. (2006), An eastern Tethyan (Tibetan) record of the Early Jurassic (Toarcian) mass extinction event, Geobiology, 4, 179-190, doi:10.1111/j.1472-4669.2006.00081.x.

Wignall, P. B., et al. (2010), An 80 million year oceanic redox history from Permian to Jurassic pelagic sediments of the Mino-Tamba terrane, SW Japan, and the origin of four mass extinctions, Global Planet. Change, 71, 109-123, doi:10.1016/j.gloplacha.2010.01.022.

Winguth, A. M. E., and E. Maier-Reimer (2005), Causes of marine productivity and oxygen changes associated with the Permian-Triassic boundary: A reevaluation with ocean general circulation models, Mar. Geol., 217, 283-304, doi:10.1016/j.margeo.2005.02.011.

Winguth, A. M. E., C. Heinze, J. E. Kutzbach, E. Maier-Reimer, U. Mikolajewicz, D. Rowley, A. Rees, and A. M. Ziegler (2002), Simulated warm polar currents during the middle Permian, Paleoceanography, 17(4), 1057, doi:10.1029/2001PA000646.

Zakharov, V., et al. (2006), Pliensbachian-Toarcian biotic turnover in north Siberia and the Arctic region, Stratigr. Geol. Correl., 14, 399-417, doi:10.1134/S0869593806040046.

Ziegler, A. M., et al. (1993), Early Mesozoic phytogeography and climate, Philos. Trans. R. Soc. London B, 341, 297-305, doi:10.1098/rstb.1993. 0115 .

Ziegler, A. M., et al. (2004), Tracing the tropics across land and sea: Permian to present, Lethaia, 366, 227-254. 